OPEN ACCESS

Edited by:

Hae-Won Kim,

Institute of Tissue Regeneration Engineering (ITREN), South Korea

Reviewed by: Kunyu Zhang, Johns Hopkins University,

United States

Jung-Hwan Lee,

Institute of Tissue Regeneration Engineering (ITREN), South Korea

*Correspondence: Oscar Kuang-Sheng Lee oscarlee9203@gmail.com

†These authors have contributed equally to this work

Specialty section:

This article was submitted to Biomaterials,

a section of the journal Frontiers in Bioengineering and Biotechnology

Received: 24 July 2020 Accepted: 28 October 2020 Published: 26 November 2020

Citation:

Xu H, Lee C-W, Wang Y-F, Huang S, Shin L-Y, Wang Y-H, Wan Z, Zhu X, Yung PSH and Lee OK-S (2020)

The Role of Paracrine Regulation of Mesenchymal Stem Cells in the Crosstalk With Macrophages in Musculoskeletal Diseases: A Systematic Review. Front. Bioeng. Biotechnol. 8:587052. doi: 10.3389/fbioe.2020.587052

\section{The Role of Paracrine Regulation of Mesenchymal Stem Cells in the Crosstalk With Macrophages in Musculoskeletal Diseases: A Systematic Review}

\author{
Hongtao X ${ }^{1+}$, Chien-Wei Lee ${ }^{1,2,3 \dagger}$, Yu-Fan Wang ${ }^{1}$, Shuting Huang ${ }^{2}$, Lih-Ying Shin ${ }^{1}$, \\ Yu-Hsuan Wang ${ }^{1}$, Zihao Wan ${ }^{1}$, Xiaobo Zhu ${ }^{1}$, Patrick Shu Hang Yung ${ }^{1}$ and \\ Oscar Kuang-Sheng Lee ${ }^{1,2,4,5 *}$
}

${ }^{1}$ Department of Orthopaedics and Traumatology, Faculty of Medicine, Prince of Wales Hospital, The Chinese University of Hong Kong, Hong Kong, China, ${ }^{2}$ Institute for Tissue Engineering and Regenerative Medicine, The Chinese University of Hong Kong, Hong Kong, China, ${ }^{3}$ Developmental and Regenerative Biology TRP, Faculty of Medicine, School of Biomedical Sciences, The Chinese University of Hong Kong, Hong Kong, China, ${ }^{4}$ Faculty of Medicine, Li Ka Shing Institute of Health Sciences, Prince of Wales Hospital, The Chinese University of Hong Kong, Hong Kong, China, ${ }^{5}$ Department of Orthopadics, China Medical University Hospital, Taichung, Taiwan

The phenotypic change of macrophages ( $\mathrm{M} \varphi \mathrm{s}$ ) plays a crucial role in the musculoskeletal homeostasis and repair process. Although mesenchymal stem cells (MSCs) have been shown as a novel approach in tissue regeneration, the therapeutic potential of MSCs mediated by the interaction between MSC-derived paracrine mediators and $\mathrm{M} \varphi$ s remains elusive. This review focused on the elucidation of paracrine crosstalk between MSCs and $\mathrm{M} \varphi s$ during musculoskeletal diseases and injury. The search method was based on the PRISMA (Preferred Reporting Items for Systematic Reviews and Meta-Analyses) and Cochrane Guidelines. The search strategies included MeSH terms and other related terms of MSC-derived mediators and M $\varphi s$. Ten studies formed the basis of this review. The current finding suggested that MSC administration promoted proliferation and activation of $\mathrm{CD}_{163^{+}}$or $\mathrm{CD} 206^{+} \mathrm{M} 2 \mathrm{M} \varphi$ s in parallel with reduction of proinflammatory cytokines and increase in anti-inflammatory cytokines. During such period, M $\varphi$ s also induced MSCs into a motile and active phenotype via the influence of proinflammatory cytokines. Such crosstalk between M $\varphi$ s and MSCs further strengthens the effect of paracrine mediators from MSCs to regulate $M \varphi s$ phenotypic alteration. In conclusion, MSCs in musculoskeletal system, mediated by the interaction between MSC paracrine and $\mathrm{M} \varphi \mathrm{s}$, have therapeutic potential in musculoskeletal diseases.

Keywords: mesenchymal stem cells (MeSH ID D059630), extracellular vesicles (EVs), exosomes, macrophages, musculoskeletal

\section{INTRODUCTION}

The inflammatory processes in response to musculoskeletal diseases and injury, such as bone fractures, osteoarthritis (OA), osteoporosis, tendon injuries, and muscle injuries, are essential for the correct restoration of structure and function to the affected area (Bosurgi et al., 2011; Mianehsaz et al., 2019; Pajarinen et al., 2019; Wang et al., 2019; Yang and Yang, 2019). However, 
the dysregulation of inflammatory reactions can aggravate the tissue healing results (Saldana et al., 2019).

Macrophages $(\mathrm{M} \varphi \mathrm{s})$ are the critical regulators involved in initiation, propagation, and resolution of inflammatory response throughout the tissue regenerative process. $\mathrm{M} \varphi$ s have a broad spectrum of adaptive phenotypes and functional transitions that might exacerbate and resolve inflammation during tissue repair process (Saldana et al., 2019). In 2008, Mosser and Edwards analyzed the phenotypic changes of $\mathrm{M} \varphi$ s and robustly classified M $\varphi$ s into two types: M1 and M2 (Mosser and Edwards, 2008). Proinflammatory $\mathrm{M} \varphi$ s are identified as the classic $\mathrm{M} 1 \mathrm{M} \varphi \mathrm{s}$, which are involved in the early stages of tissue repair, whereas the anti-inflammatory $\mathrm{M} \varphi$ s are identified as $\mathrm{M} 2 \mathrm{M} \varphi \mathrm{s}$, which dominated later stages of tissue repair (Murray et al., 2014; Spiller and Koh, 2017). Upon injury, the early presence of M1 $\mathrm{M} \varphi$ s initiates tissue repair, but the persistent of M1 activity can deteriorate the repair process (Krzyszczyk et al., 2018). On the other hand, the early presence of M2 can prevent cellular and vascular infiltration that impairs tissue development through ectopic secretion of fibrotic chemokines and cytokine (Stahl et al., 2013; Bility et al., 2014; Moore et al., 2015). Moreover, several different M2 subtypes have been identified, including M2a, M2b, M2c, and M2d (Stein et al., 1992; Donnelly et al., 1999; Anderson and Mosser, 2002). The undisciplined regulation of $\mathrm{M} \varphi$ phenotypic change impairs tissue repair, and each of the subtypes might have specific functions; therefore, further investigation is needed to identify the explicit role of M2 subtypes (O’Brien et al., 2019).

In the 1980's, Arnold Caplan and his colleagues published an isolation method of fibroblast-like stromal cells from bone marrow and first identified them as mesenchymal stem cells (MSCs) because of their multilineage differentiation potential (Caplan, 1991). A rapid expansion in the field of MSC-based therapy in immunomodulation and regenerative medicine has been acknowledged (Kingery et al., 2019). It has been reported that MSCs can switch M1 M $\varphi$ s or resting M $\varphi$ s into M2 M $\varphi$ s (Kim and Hematti, 2009; Nemeth et al., 2009; Melief et al., $2013 b)$. Previous studies showed that prostaglandin $\mathrm{E}_{2}\left(\mathrm{PGE}_{2}\right)$, interleukin-4 (IL-4), IL-6, and IL-10 released from MSCs can induce the $\mathrm{M} \varphi$ polarization toward $\mathrm{M} 2$ to accelerate tissue regeneration (da Costa Goncalves and Paz, 2019). On the other hand, such immunomodulatory ability of MSCs is adjusted by inflammatory factors released by macrophages (Waterman et al., 2010; Carrero et al., 2012). After the stimulation, MSCs would secrete anti-inflammatory factors, such as transforming growth factor $\beta$ (TGF- $\beta$ ) and CCL-18, to further suppress activation of lymphocytes and inhibit major histocompatibility complex (MHC) class II and CD86 in lipopolysaccharide (LPS)stimulated $\mathrm{M} \varphi$ s (Melief et al., 2013b; Cho et al., 2014). This suggested that the interplay between MSCs and $\mathrm{M} \varphi$ s is in control of inflammation, and their crosstalk may be recommended to advocate tissue healing or repair.

Besides versatile soluble proteins, MSC-derived extracellular vesicles (MSC-EVs) have raised worldwide attention in regenerative medicine because of their immunomodulation ability (Raposo and Stoorvogel, 2013). EVs represent a heterogeneous group of cell-derived membranous vesicles, such as microvesicles (MVs) and exosomes, which were first described in the 1970's (Vakhshiteh et al., 2019). MVs, ranging from 40 to 2,000 $\mathrm{nm}$ in diameter (Bruno et al., 2012; Kim et al., 2012), and exosomes, ranging from 30 to $150 \mathrm{~nm}$ in diameter (Li et al., 2013; Zhao et al., 2015), are critical mediators for intercellular communication via the delivery of the embedded RNAs, DNAs, and cytosolic proteins. Moreover, boosting the therapeutic potential of MSC-EVs by changing the intrinsic bioactive factors or modifying membrane by bioengineering approach is possible (Lu and Huang, 2020). Refining the culture condition of MSCs could significantly increase the production yield and improve the efficacy of MSC-EVs (Luan et al., 2017; Willis et al., 2017; Bagno et al., 2018; Cha et al., 2018; Ferguson et al., 2018). Also, MSC-derived EVs could serve as a promising drug delivery vector, owing to their high biocompatibility, high efficacy of delivery, and low immunogenicity (Clayton et al., 2003; Ridder et al., 2014; Zomer et al., 2015). EVs derived from different origins have preferential targeting cells due to their distinct membrane composition gained from their parental cells that impart differential effect on body systems (Luan et al., 2017; Ferguson et al., 2018), which could be addressed by exploiting the nature of EVs as natural carriers of miRNA or other molecules by considering them as drug delivery vehicles (Cheng et al., 2017). In addition, MSC-derived EVs in conjunction with other materials might provide substantial advances in both immunomodulation and tissue regeneration (Cosenza et al., 2018). And it has been reported that a variety of material's environment could affect cell's downstream response by cell-material interactions (Darnell et al., 2018). Taken together, bioengineered MSC-derived EVs are novel adjustable biomaterials for tissue regeneration.

The therapeutic effect of MSCs showed a clinical benefit in children suffering from osteogenesis imperfecta (Otsuru et al., 2012) and preclinical benefit in bone fracture (Li Y. et al., 2019), OA (Cosenza et al., 2017), tendon injury (Chamberlain et al., 2019), pulmonary hypertension (Lee et al., 2012), cancer (Silva et al., 2013), and infectious diseases (Cheng and Schorey, 2013). The mechanisms of these mentioned therapeutic potentials of MSCs need elucidation. This review aimed to expound the role of MSC paracrine, especially MSC-derived EVs, in the crosstalk with $\mathrm{M} \varphi \mathrm{s}$ in musculoskeletal diseases. Moreover, a systemic understanding of MSC-EVs properties and activities will provide a solid foundation to boost MSC-EVs for regenerative medicine and will significantly facilitate the translation value of MSC-based therapy (Zhang et al., 2020).

\section{METHODS}

The Preferred Reporting Items for Systematic Reviews and Meta-Analyses (PRISMA) statement was used for this article. Meanwhile, the Cochrane handbook was selected as guidelines for the study protocol (Moher et al., 2009).

\section{Search Strategy and Study Selection}

Two different investigators (H.-T.X., L.-Y.S.) conducted the customized up-to-date literature search. PubMed database and EMBASE (Excerpta Medica Database) database were selected in this study. 
The title and abstract field were selected to search for MeSH terms and other related terms, which pertained to "Mesenchymal Stem Cells," "Macrophages," and "Paracrine Regulation," such as "Exosomes," "Extracellular Vesicles" and "Culture Media, Conditioned." The details of selected search terms and searching procedures that were used in the individual database are available in Appendices 1-3 in Supplementary Material. Additional studies were also located by searching papers referenced in listed articles. Those studies identified by the search outcomes were combined, and duplicates were excluded. Then, the screening procedure of titles and abstracts was performed before elaboration on the selected full-text articles. Two investigators (H.-T.X., L.-Y.S.) screened the titles and abstracts of those identified studies individually. In cases of disagreement between the two authors, a consensus was reached by discussion with a third author (C.-W.L.). After that, the full text of screened

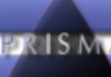

PRISMA 2009 Flow Diagram
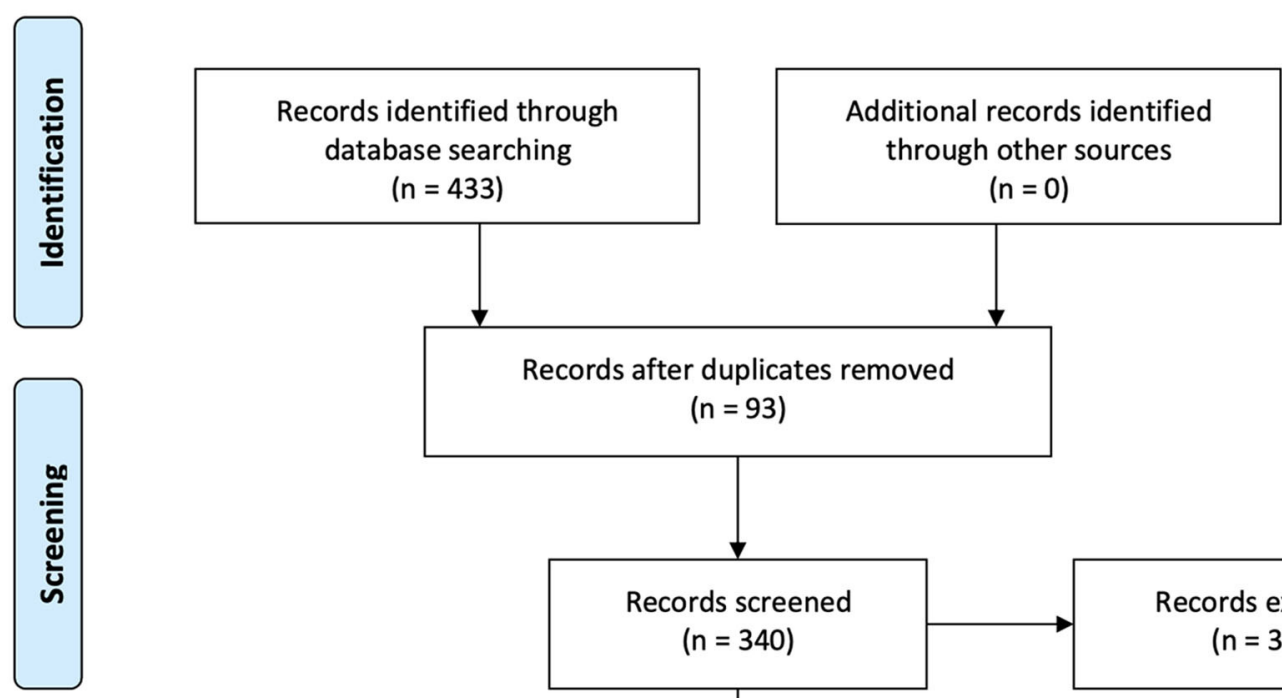

Records after duplicates removed

$(n=93)$
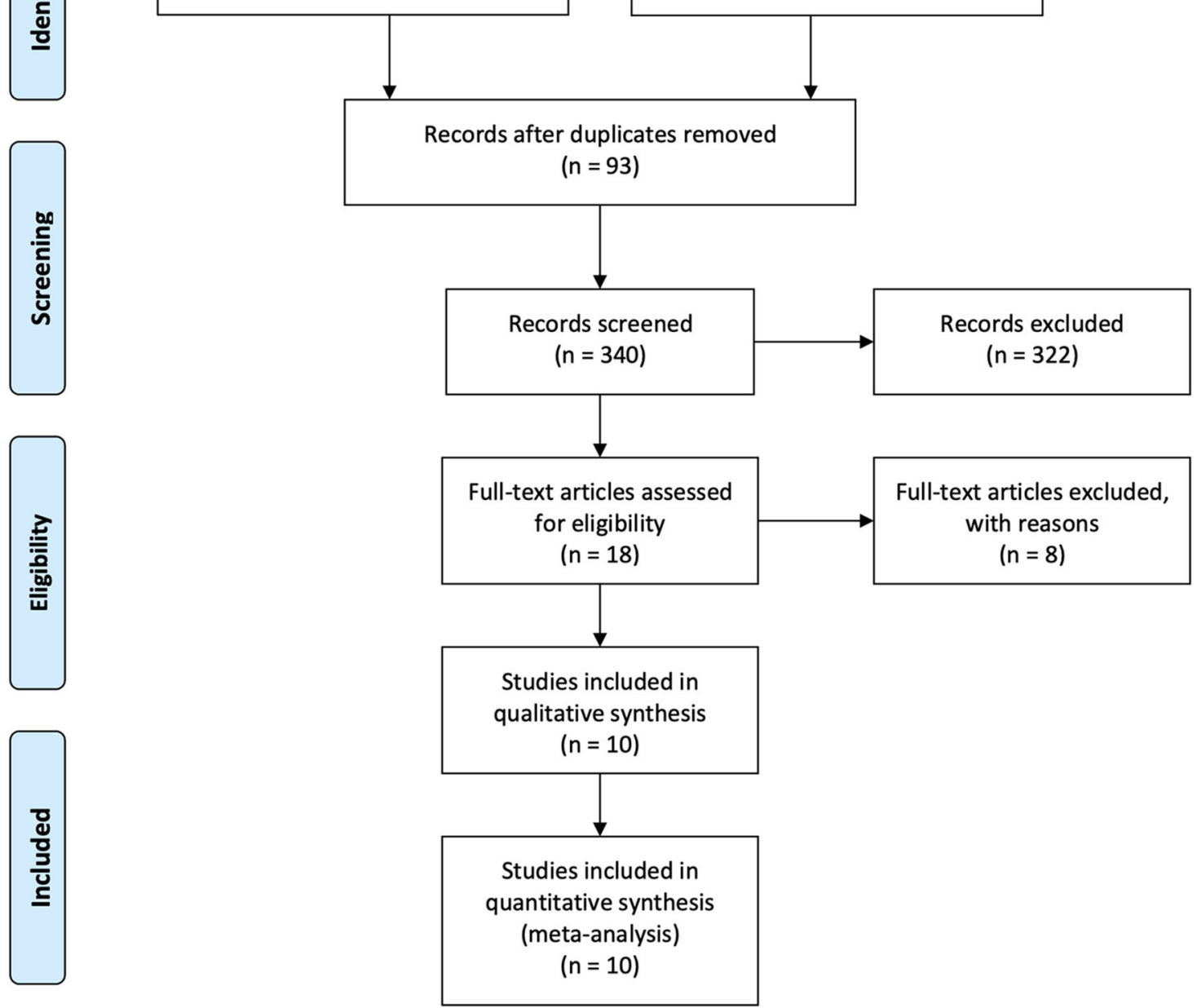

FIGURE 1 | Flowchart presenting the results of the literature search and the strategy used to select studies that relate to the crosstalk between MSCs and M $\varphi$ S of musculoskeletal diseases. Study selection process. The search revealed 433 records. A total of 93 overlaps were removed between the databases. The remaining 340 records were screened by title and abstract, and 322 records were excluded. The remaining 18 studies were examined using their full texts, and finally ten eligible studies were identified. 
articles were examined. Corresponding authors of the reviewed articles could be contacted with essential needs to obtain those missing data.

The search yielded 433 studies across all databases (239 studies across PubMed database and 194 studies across EMBASE database). A total of 93 duplicates were removed. According to the inclusion and exclusion criteria, all these studies were screened and reviewed by titles and abstracts first; 322 studies were excluded because they were review articles, case reports, case series, letters, chapters, or studies published more than 10 years ago. Of the 18 remaining studies, which were applied by a filter to include musculoskeletal-related studies, eight studies were excluded via reviewing full text. The 10 remaining studies underwent secondary full-text review and were confirmed as fitting the inclusion criteria. The flowchart of the selected studies selection process, which was based on the PRISMA 2009 Flow Diagram (Moher et al., 2009), is shown in Figure 1, and the details of inclusion and exclusion criteria are shown in Table $\mathbf{1 .}$

\section{Data Extraction}

All relevant data were extracted by H.-T.X. and X.-B.Z.: author information, published journal, year of publication, sample source, target disease, study type (in vivo, in vitro, or both), cell management, and measurement instrument. The details of results extraction consisted of variable/control group descriptions, laboratory effects, proposed mechanisms, article conclusions, and research implications. After that, the selected articles were classified according to the type of target disease.

\section{Methodological Quality Assessment}

The methodological assessment should be used as an essential procedure, which could exclude articles with a large degree of bias or with a higher degree of potential bias, has been highlighted to readers (McElvany et al., 2015). Identified studies fitting all criteria were reviewed, and all included data were extracted and analyzed based on study heterogeneity and methodological quality. Because of the natural heterogeneity of measurement across studies, a meta-analysis could not be performed. Two independent authors (H.-T.X. and Z.-H.W.) separately assessed and graded the methodological quality of all selected studies. Disagreements between the two independent researchers were identified and resolved by discussion with a third reviewer (C.-W.L.). The selected studies were assessed with a quality scoring system raised by Wells and Julia (2009) (Appendix 4 in Supplementary Material). The quality assessment system was based on the following eight questions: Was the study hypothesis/aim/objective clearly described? Were the animal models for the study well-described? Were the methods welldescribed? Were the data collection time point clearly defined? Were the main outcome measures clearly defined? Were the experiment group well-compared with the control group? Were the results well-described? Were the articles discussed the limitation? For each question, 1 point was allocated for "yes," and 0 point was allocated for "no." The number of "yes" answers was counted for each selected study to give a total score out of 8. A study's rating was considered as excellent with a score ranging from 6 to 8 , good with a score ranging from 4 to 6 , poor with
TABLE 1 | Inclusion and exclusion criteria.

\begin{tabular}{|c|c|}
\hline Criteria & \\
\hline \multirow[t]{6}{*}{ Inclusion criteria } & 1. Full-text available; \\
\hline & 2. Written in English; \\
\hline & 3. Articles published in the last 10 years; \\
\hline & 4. Articles containing original data; \\
\hline & $\begin{array}{l}\text { 5. Studies must be related to "mesenchymal } \\
\text { stem cells" and "macrophages"; }\end{array}$ \\
\hline & 6. Musculoskeletal related studies. \\
\hline \multirow[t]{4}{*}{ Exclusion criteria } & 1. No control group; \\
\hline & 2. Sampling method described inconsistent; \\
\hline & $\begin{array}{l}\text { 3. Case reports, case series and review } \\
\text { articles, letter, chapter; }\end{array}$ \\
\hline & 4. Not available in the English language. \\
\hline
\end{tabular}

a score ranging from 2 to 4 , and bad with a score ranging from 0 to 2 .

\section{RESULTS}

\section{Study Methodology Quality Assessment}

The scoring system was used to calculate all ten selected studies in Appendix 5 in Supplementary Material. The mean score is 6.6 (range, 5-8), including eight studies exceeding 6 points (Cosenza et al., 2017; Lo Sicco et al., 2017; Hyvarinen et al., 2018; Zhang et al., 2018; Chamberlain et al., 2019; Li Y. et al., 2019; Shi et al., 2019; Shen et al., 2020).

\section{Study Characteristics}

Of the ten selected studies, one study was published in 2015 (Chang et al., 2015), two were published in 2017 (Cosenza et al., 2017; Lo Sicco et al., 2017), two studies were published in 2018 (Hyvarinen et al., 2018; Zhang et al., 2018), four studies were published in 2019 (Chamberlain et al., 2019; Li Y. et al., 2019; Pacienza et al., 2019; Shi et al., 2019), and the final one was published in 2020 (Shen et al., 2020) (Figure 2A). All selected studies were related to the musculoskeletal system. For details of target diseases, two studies were bone fracture-related studies (Chang et al., 2015; Li Y. et al., 2019), two studies were OArelated studies (Cosenza et al., 2017; Zhang et al., 2018), one study was a muscle damage-related study (Lo Sicco et al., 2017), three studies were tendon injury-related studies (Chamberlain et al., 2019; Shi et al., 2019; Shen et al., 2020), and the other two studies were included without targeting disease (Hyvarinen et al., 2018; Pacienza et al., 2019) (Figure 2B). Six studies used a mice model (Cosenza et al., 2017; Lo Sicco et al., 2017; Chamberlain et al., 2019; Li Y. et al., 2019; Pacienza et al., 2019; Shen et al., 2020), two studies used a rat model (Zhang et al., 2018; Shi et al., 2019), and two studies performed in vitro experiments only (Chang et al., 2015; Hyvarinen et al., 2018) (Figure 2C). Three paracrine factors were extracted from the results: MSCderived exosomes (Cosenza et al., 2017; Zhang et al., 2018; Pacienza et al., 2019; Shen et al., 2020), MSC-derived EVs (Lo Sicco et al., 2017; Hyvarinen et al., 2018; Chamberlain et al., 
A

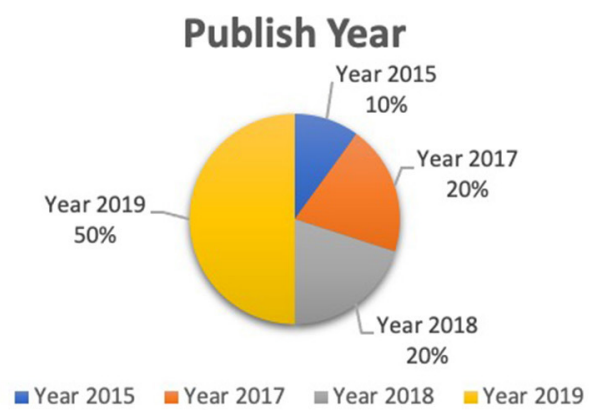

C

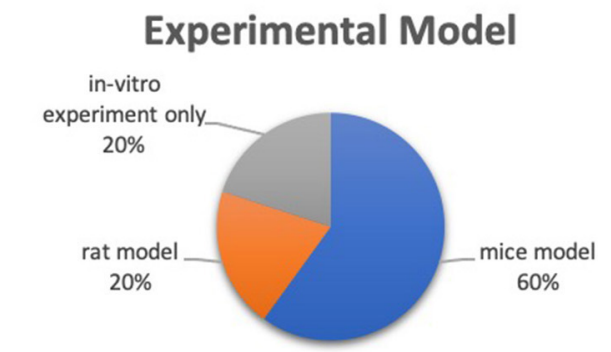

amice model $\quad$ rat model $\quad$ in-vitro experiment only
B

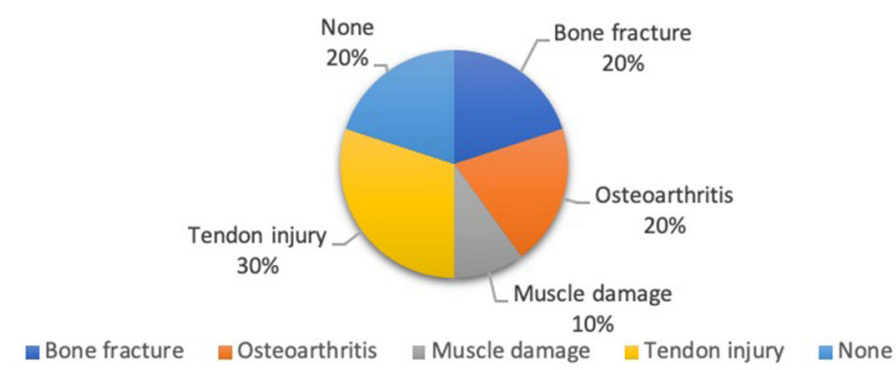

D

Paracrine Factor

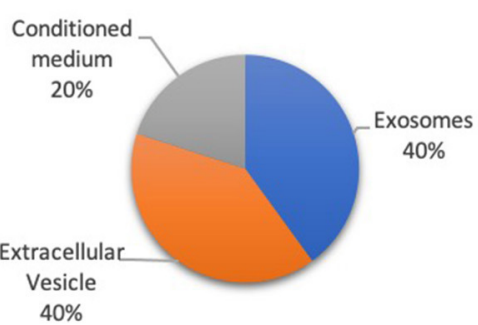

Exosomes Extracellular Vesicle Conditioned medium

E

\section{Cell Source}

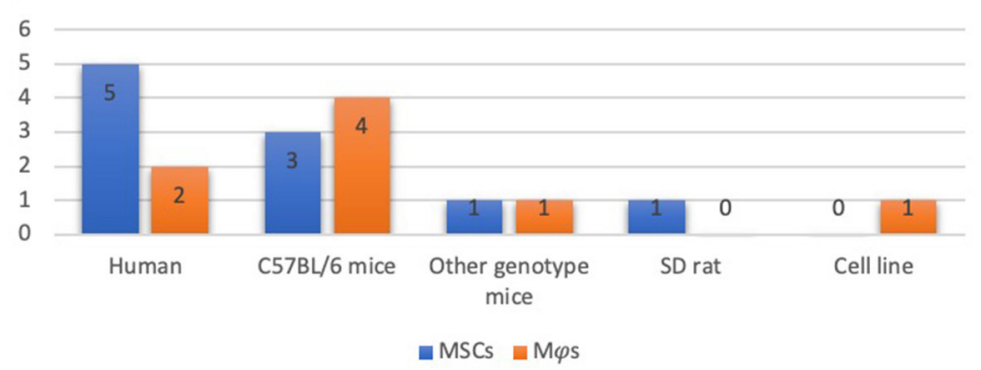

FIGURE 2 | Representative graph of the included studies presented in the articles reviewed. (A) Publication year of included studies (range from 2015 to 2020). (B) Target disease of included studies (include bone fracture, OA, muscle damage, tendon injury). (C) Experimental model of included studies (including mice model, rat model, in vitro experiment only). (D) Paracrine factors (including extracellular vesicle, exosomes, CM). (E) Cell source of included studies (including human, C57BI/6 mice, other genotype mice, SD rat, cell line).

2019; Shi et al., 2019), and MSC-derived conditioned medium (CM) (Chang et al., 2015; Li Y. et al., 2019) (Figure 2D). Five MSC and $\mathrm{M} \varphi$ s cell sources for EVs isolation were described in these selected studies: human (Lo Sicco et al., 2017; Hyvarinen et al., 2018; Zhang et al., 2018; Chamberlain et al., 2019; Pacienza et al., 2019), cell lines (Pacienza et al., 2019), Sprague-Dawley rats (Shi et al., 2019), C57BL/6 mice (Chang et al., 2015; Cosenza et al., 2017; Lo Sicco et al., 2017; Li Y. et al., 2019), and transgenic mice [scleraxis-green fluorescent protein (GFP) tendon reporter mice, nuclear factor (NF-кB)-GFP-luciferase transgenic reporter mice, and wild-type FVB/NJ (FVB) mice] (Shen et al., 2020). The detailed data are graphically shown in Figure 2E.

\section{Target Diseases and Experimental Animal Models}

In the bone fracture-related studies (Chang et al., 2015; Li Y. et al., 2019), Li Y. et al. (2019) established a cylindrical bone defect mice model by using an electric drill to make a defect with 1-mm diameter and 1-mm depth at the bone callus of the femur. Chang et al. (2015) studied only in vitro experiments, and they cocultured bone marrow-derived mesenchymal stem cells (BMSCs) with $\mathrm{M} \varphi$ s. Two studies selected OA as the target disease (Cosenza et al., 2017; Zhang et al., 2018). Cosenza et al. (2017) established a collagenase-induced arthritis mouse model by intra-articularly injecting $1 \mathrm{U}$ type VII collagenase (in $5 \mu \mathrm{L}$ saline) into the knee joint of 10 -week-old C57BL/6 mice at days 
0 and 2. Zhang et al. (2018) generated an osteochondral defect model in an 8-week-old Sprague-Dawley rat. Osteochondral defects, with 1.5-mm diameter and 1-mm depth, were generated on the trochlear grooves of the distal femurs by a drill bit. For muscle injury study, cardiotoxin-induced muscle injury was applied in 8-week-old male C57BL/6 mice by intramuscular administration of cardiotoxin into the Tibialis Anterior (TA) muscle (Lo Sicco et al., 2017). Three tendon injury models were used in the selected studies (Chamberlain et al., 2019; Shi et al., 2019; Shen et al., 2020). Chamberlain et al. (2019) established a surgically transected Achilles tendon mouse model. After superficial digital flexor tendon was removed, the Achilles tendon was completely transected at the midpoint. Then tendon was sutured together by using 5-0 Vicryl suture. In Shen et al. (2020) study, Achilles tendon was two-thirds transected at the midpoint part between calcaneal insertion and the musculotendinous junction and then was sutured with a twostrand modified Kessler technique. Shi et al. (2019) applied the Sprague-Dawley rat patellar tendon defect model. Briefly, the central one-third of the patellar tendon was removed from the distal apex of the patellar to the insertion of the tibial tuberosity to achieve a tendon structural defect condition. In addition, Pacienza et al. (2019) established a mouse endotoxemia model by injecting LPS via tail vein, which was used to study the crosstalk between MSC-derived exosomes and $\mathrm{M} \varphi$ s. Hyvarinen et al. (2018) only cocultured BMSCs and BMSCderived EVs with $\mathrm{M} \varphi$ s without preforming animal study. The target diseases and experimental models are represented in Table 2 in detail.

\section{Cell Sources and Cell Management}

Five of 10 studies used human source cells (Lo Sicco et al., 2017; Hyvarinen et al., 2018; Zhang et al., 2018; Chamberlain et al., 2019; Pacienza et al., 2019). Human adipose-derived mesenchymal stem cells (ADSCs) were used for in vitro experiments in Lo Sicco's research; the EVs derived from ADSCs were cocultured with mouse $\mathrm{M} \varphi$ s and intralesionally injected into the mouse muscle injury model (Lo Sicco et al., 2017). In Hyvarinen et al. (2018) study, they used human BMSCs or BMSC-derived EVs to coculture with human $\mathrm{M} \varphi \mathrm{s}$. Zhang et al. (2018) intra-articularly injected exosomes from human embryonic stem cell-derived MSCs into rat with osteochondral defect. Chamberlain et al. (2019) also used human BMSCs and $\mathrm{M} \varphi s$ for the in vitro experiment. BMSCs, $\mathrm{CD} 14^{+} \mathrm{M} \varphi \mathrm{s}$ and exosome-educated $\mathrm{M} \varphi$ s were intralesionally injected in the mice with Achilles tendon injury. Pacienza et al. (2019) used human BMSCs and RAW 264.7 for the in vitro experiment. Exosomes derived from BMSCs were intravenously injected into the endotoxemia mouse model. The in vitro experiment cell sources were all C57BL/6 mice in Chang et al. (2015), Cosenza et al. (2017) and Li Y. et al. (2019) studies. Fibrin containing SpragueDawley rat BMSC-derived EVs was intralesionally injected into the patellar tendon defect rat in Shi et al. (2019) study. Shen et al. (2020) used an in vitro model whose cell source was isolated from specific transgenic mice. The details of cell management are summarized in Table 2.

\section{Boosting Approaches for MSC-Paracrine Mediators}

Lo Sicco et al. (2017) isolated ADSC-derived EVs from normoxic and hypoxic culture condition. Li Y. et al. (2019) used a Transwell coculture system of ADSCs and $\mathrm{M} \varphi$ s without extra management of MSCs paracrine mediators. The other eight studies collected and purified EVs or other paracrine mediators from MSC-derived CM by differential centrifugation approaches (Chang et al., 2015; Cosenza et al., 2017; Lo Sicco et al., 2017; Hyvarinen et al., 2018; Zhang et al., 2018; Chamberlain et al., 2019; Pacienza et al., 2019; Shi et al., 2019; Shen et al., 2020). The detailed methods are described in Table 2.

\section{Measurement Instruments}

For classifications on the results, the measurement instruments, including immunohistochemistry, reverse transcriptasepolymerase chain reaction analysis, Western blot analysis, enzyme-linked immunosorbent assay, flow cytometry analysis, multiplex cytokine assay, confocal laser scanning, microcomputed tomography, and mechanical testing, were used. Also, fractal analysis (Chamberlain et al., 2019) and bone parameter analysis (Cosenza et al., 2017) were applied. Detailed results are listed in Table 2.

\section{Experimental Variables and Controls}

For two bone fracture-related studies, Li Y. et al. (2019) locally injected a total of $1 \times 10^{6}$ ADSCs at the injury site of their cylindrical bone defect model; the therapeutic efficacy of ADSCs was compared to the non-injected group. In the in vitro experiment, the bone marrow-derived $\mathrm{M} \varphi$ s were cocultured with $1 \times 10^{5}$ ADSCs in the upper chamber of Transwell under with high-glucose Dulbecco modified eagle medium containing 10\% fetal bovine serum (FBS). Chang et al. (2015) planted $1 \times 10^{5}$ bone marrow-derived $\mathrm{M} \varphi$ s into six-well plates and cultured $24 \mathrm{~h}$. Then, $1 \times 10^{5}$ BMSCs or apoptotic BMSCs (exposed to UV light treatment for $30 \mathrm{~min}$ ) were placed on the $\mathrm{M} \varphi$ s in $\alpha$-minimum essential medium containing $10 \% \mathrm{FBS}$. For each time point, $\mathrm{M} \varphi \mathrm{s}$ cultured alone, apoptotic BMSCs cultured alone, and BMSCs cultured alone served as control groups.

For the OA-related studies, Cosenza et al. (2017) applied the in vitro OA-like chondrocytes model to investigate the effect of microparticles, BMSC-derived exosomes, BMSC-derived CM, and BMSCs on $\mathrm{M} \varphi s$ in a Transwell system. For their in vivo experiment, BMSCs, microparticles, and exosomes were intraarticularly injected into the arthritis model. Those OA mice without treatment served as a control group. In Zhang et al. (2018) study, exosomes and phosphate-buffered saline (PBS) (used as control) were intra-articularly injected into the rat osteochondral defect model after surgery, respectively.

For three tendon injury-related studies, two of them (Chamberlain et al., 2019; Shen et al., 2020) reported the coculture results of EVs and $\mathrm{M} \varphi \mathrm{s}$, and the another one study reported in vivo experiment (Shi et al., 2019). Chamberlain et al. (2019) reported that exosome-educated $\mathrm{M} \varphi$ s could be generated by MSC-derived EVs, and $\mathrm{M} \varphi$ s treated with PBS served as control groups in their in vitro experiment. To compare the therapeutic potential on tendon healing, the authors intralesionally injected 
TABLE 2 | Study characteristics and outcomes.

\begin{tabular}{|c|c|c|c|c|c|c|c|c|}
\hline Author & Journal & Year & Cell source & $\begin{array}{l}\text { Target } \\
\text { disease }\end{array}$ & $\begin{array}{l}\text { Study } \\
\text { type }\end{array}$ & Cells management & $\begin{array}{l}\text { Bioengineering method for MSCs } \\
\text { paracrine mediators }\end{array}$ & Measurement instrument \\
\hline Chang J & Bone Res & 2015 & C57BL/6 mice & $\begin{array}{l}\text { Bone } \\
\text { fracture }\end{array}$ & In-vitro & $\begin{array}{l}\mathrm{BMSC} \mathrm{CM} \text { and } \mathrm{M} \varphi \mathrm{S} \\
\text { cell contract co-culture }\end{array}$ & $\begin{array}{l}\text { BMSCs intrinsic bio-activation: the } \\
\text { supernatants from BMSCs cultures were } \\
\text { collected and stored at }-80^{\circ} \mathrm{C} \text { until used as } \\
\text { conditioned medium. }\end{array}$ & $\begin{array}{l}\text { Scratch assay, BMSCs migration } \\
\text { assay, IL-6 ELISA assay, cell growth } \\
\text { assay, Gene expression by RT-PCR, } \\
\text { Western blot }\end{array}$ \\
\hline $\begin{array}{l}\text { Cosenza } \\
\text { et al., } 2017\end{array}$ & Sci Rep & 2017 & C57BL/6 mice & Osteoarthritis & $\begin{array}{l}\text { In-vitro and } \\
\text { in-vivo }\end{array}$ & $\begin{array}{l}\text { In-vitro: BMSC Exos } \\
\text { and M } \varphi \text { S } \\
\text { In-vivo (arthritis model): } \\
\text { IA injections of } \\
\text { BM-MSCs, MPs } \\
\text { or Exos. }\end{array}$ & $\begin{array}{l}\text { BMSCs intrinsic bio-activation: BMSC-CM was } \\
\text { centrifuged at } 300 \mathrm{~g} \text { for } 10 \mathrm{~min} \text { to eliminate } \\
\text { cells and } 2,500 \mathrm{~g} \text { for } 25 \mathrm{~min} \text { to remove debris } \\
\text { and apoptotic bodies. For MP isolation, CM } \\
\text { was centrifuged at } 18,000 \mathrm{~g} \text { for } 1 \mathrm{~h} \text { in } \\
\text { polyallomer tubes; the pellet was then } \\
\text { suspended in PBS and submitted to a second } \\
\text { round of centrifugation. For Exos, supernatant } \\
\text { from MP fraction was filtered on } 0.22 \mu \mathrm{m} \\
\text { porous membrane and centrifuged at } \\
100,000 \mathrm{~g} \text { for } 2 \mathrm{~h} \text {. }\end{array}$ & $\begin{array}{l}\text { Flow cytometry analysis, Bone } \\
\text { parameter analyses, Confocal laser } \\
\text { scanning microscopy, Histological } \\
\text { analysis }\end{array}$ \\
\hline Lo Sicco & $\begin{array}{l}\text { Stem Cells } \\
\text { Transl Med }\end{array}$ & 2017 & $\begin{array}{l}\text { Human-ADSCs; } \\
\text { C57BL/6 } \\
\text { mice-M } \varphi \text { s }\end{array}$ & $\begin{array}{l}\text { Muscle } \\
\text { damage }\end{array}$ & $\begin{array}{l}\text { In-vitro and } \\
\text { in-vivo }\end{array}$ & $\begin{array}{l}\text { In-vitro: ADSC EVs and } \\
\mathrm{M} \varphi \mathrm{S} \\
\text { In-vivo (muscle injury } \\
\text { model): IL injection of } \\
\text { ADSCs EVs }\end{array}$ & $\begin{array}{l}\text { ADSCs extrinsic modification: ADSC EVs were } \\
\text { isolated from normoxic- and } \\
\text { hypoxic-conditioned media by differential } \\
\text { centrifugation at } 300 \mathrm{~g} \text { for } 10 \mathrm{~min}, 2,000 \mathrm{~g} \text { for } \\
20 \mathrm{~min}, 10,000 \mathrm{~g} \text { for } 30 \mathrm{~min} \text { at } 4^{\circ} \mathrm{C} \text { to eliminate } \\
\text { cells and debris }\end{array}$ & $\begin{array}{l}\text { Protein quantification and immunoblot } \\
\text { analysis, Flow cytometry analysis, } \\
\text { qRT-PCR, Immunofluorescence } \\
\text { analysis, Histology and morphometric } \\
\text { analysis }\end{array}$ \\
\hline $\begin{array}{l}\text { HyvÃ@rinen } \\
\text { K }\end{array}$ & $\begin{array}{l}\text { Front } \\
\text { Immunol }\end{array}$ & 2018 & Human & / & In-vitro & $\begin{array}{l}\text { BMSCs or BMSC-EVs } \\
\text { and } \mathrm{M} \varphi s \text { co-culture }\end{array}$ & $\begin{array}{l}\text { BMSCs intrinsic bio-activation: BMSCs media } \\
\text { were collected and centrifuged at 2,000 g for } \\
10 \text { min to remove cell debris. The supernatant } \\
\text { was ultracentrifuged with OptimaTM MAX-XP } \\
\text { Ultracentrifuge (Beckman Coulter) at } 100,000 \mathrm{~g} \\
1.5 \mathrm{~h}+4^{\circ} \mathrm{C} \text { with MLA-50 rotor ( } \mathrm{k} \text {-factor }=92 \text {, } \\
\text { Beckman Coulter), and the pelleted EVs were } \\
\text { combined. For the second EV collection, the } \\
\text { cell starvation was continued in } 200 \mathrm{ml} \alpha-\mathrm{MEM} \\
\text { at } 37^{\circ} \mathrm{C}, 5 \% \mathrm{CO}_{2} \text { for } 2 \text { days followed by } \\
\text { replication of } \mathrm{EV} \text { centrifugation steps. }\end{array}$ & $\begin{array}{l}\text { Flow cytometry analysis, cytokine } \\
\text { (IL-10, IL-23, IL-22) and LMs } \\
\text { measurements }\end{array}$ \\
\hline Zhang S & Biomaterials & 2018 & $\begin{array}{l}\text { Human embryonic } \\
\text { stem cell derived } \\
\text { MSCs }\end{array}$ & Osteoarthritis & In-vivo & $\begin{array}{l}\text { Sprague-Dawley rat } \\
\text { osteochondral defect } \\
\text { model: IA injection of } \\
\text { MSCs-Exos }\end{array}$ & $\begin{array}{l}\text { BMSCs intrinsic bio-activation: MSCs were } \\
\text { grown in a chemically defined medium for } 3 \\
\text { days and exosomes were purified from the CM. }\end{array}$ & $\begin{array}{l}\text { Histology and immunohistochemistry, } \\
\text { Multiplex cytokine assay (IL-1 } \beta \text {, IL-6, } \\
\text { TNF- } \beta \text { ) }\end{array}$ \\
\hline $\begin{array}{l}\text { Chamberlain } \\
\text { CS }\end{array}$ & Stem Cells & 2019 & Human & $\begin{array}{l}\text { Tendon } \\
\text { injury }\end{array}$ & $\begin{array}{l}\text { In-vitro and } \\
\text { in-vivo }\end{array}$ & $\begin{array}{l}\text { In-vitro: BMSC-EVs } \\
\text { and M } \varphi \text { s; } \\
\text { In-vivo (Foxn1nu } \\
\text { mouse model of } \\
\text { Achilles tendon injury): } \\
\text { IL injection of BMSCs, } \\
\text { CD14+ M } \varphi \text { s or EEMs }\end{array}$ & $\begin{array}{l}\text { BMSCs intrinsic bio-activation: BMSCs CM } \\
\text { was centrifuged using a Beckman Coulter } \\
\text { Allegra X-15R centrifuge at } 2,000 \mathrm{~g} \text { at } 4^{\circ} \mathrm{C} \text { for } \\
20 \text { min. Clarified supernatant CM was then } \\
\text { centrifuged in a Beckman Coulter Optima L- } 80 \\
\text { XP Ultracentrifuge at } 100,000 \mathrm{~g} \text { at } 4^{\circ} \mathrm{C} \text { for } 2 \mathrm{~h} \\
\text { with a swinging bucket SW } 28 \text { rotor to pellet } \\
\text { EVs. }\end{array}$ & $\begin{array}{l}\text { Flow cytometry analysis, } \\
\text { IHC/Immunofluorescence/Histology; } \\
\text { Fractal analysis; Mechanical testing }\end{array}$ \\
\hline
\end{tabular}


TABLE 2 | Continued

\begin{tabular}{|c|c|c|c|c|c|c|c|c|}
\hline Author & Journal & Year & Cell source & $\begin{array}{l}\text { Target } \\
\text { disease }\end{array}$ & $\begin{array}{l}\text { Study } \\
\text { type }\end{array}$ & Cells management & $\begin{array}{l}\text { Bioengineering method for MSCs } \\
\text { paracrine mediators }\end{array}$ & Measurement instrument \\
\hline Pacienza N & $\begin{array}{l}\text { Mol Ther } \\
\text { Methods Clin } \\
\text { Dev }\end{array}$ & 2019 & $\begin{array}{l}\text { Human-BMSCs; } \\
\text { RAW } \\
264.7-\mathrm{M} \varphi \text { s cell }\end{array}$ & / & $\begin{array}{l}\text { In-vitro and } \\
\text { in-vivo }\end{array}$ & $\begin{array}{l}\text { In-vitro: LPS in } \\
\text { combination with Exos } \\
\text { and M } \varphi \text { s; } \\
\text { In-vivo (endotoxemia } \\
\text { mouse model): IV } \\
\text { injection of Exos }\end{array}$ & $\begin{array}{l}\text { BMSCs intrinsic bio-activation: BMSCs CM } \\
\text { was applied directly at room temperature to a } \\
\text { column containing the anion exchange resin ( } Q \\
\text { Sepharose Fast Flow, GE Healthcare, Chicago, } \\
\text { IL, USA) that had been equilibrated with } 50 \mathrm{mM} \\
\mathrm{NaCl} \text { in } 50 \mathrm{mM} \text { phosphate buffer ( } \mathrm{pH} 7.5) \text {. The } \\
\text { column resin was washed with } 100 \mathrm{mM} \mathrm{NaCl} \text { in } \\
50 \mathrm{mM} \text { phosphate buffer ( } \mathrm{pH} 7.5 \text { ) and then } \\
\text { eluted with } 500 \mathrm{mM} \mathrm{NaCl} \text { in } 50 \mathrm{mM} \text { phosphate } \\
\text { buffer ( } \mathrm{pH} 7.5 \text { ). }\end{array}$ & $\begin{array}{l}\text { qRT-PCR, Quantitation of TNF-a, } \\
\text { IL- } 1 \beta \text {, and IL- } 6 \text { by ELISA }\end{array}$ \\
\hline Shi Z & J Transl Med & 2019 & $\begin{array}{l}\text { Sprague-Dawley } \\
\text { rats-BMSCs }\end{array}$ & $\begin{array}{l}\text { Tendon } \\
\text { injury }\end{array}$ & In-vivo & $\begin{array}{l}\text { Sprague-Dawley rat } \\
\text { patellar tendon defect } \\
\text { model: injection of fibrin } \\
\text { containing EVs }\end{array}$ & $\begin{array}{l}\text { BMSCs CM was centrifuged sequentially at } \\
300 \mathrm{~g} \text { for } 10 \text { min followed by } 2,000 \mathrm{~g} \text { for } 10 \mathrm{~min} \\
\text { to remove cellular debris. The supernatants } \\
\text { were then ultracentrifuged at } 100,000 \mathrm{~g} \text { for } 2 \mathrm{~h} \\
\text { to obtain a pellet containing the EVs, which } \\
\text { was resuspended in } 200 \mu \mathrm{L} \text { of PBS. } \\
\text { EVs-enriched fraction was centrifuged at } \\
1,500 \mathrm{~g}, 30 \mathrm{~min} \text { with } 100-\mathrm{kDa} \text { molecular weight } \\
\text { cut off (MWCO) hollow fiber membrane } \\
\text { (Millipore, Billerica, MA, USA). Then, EVs were } \\
\text { passed through a } 0.22-\mu \mathrm{m} \text { filter. }\end{array}$ & $\begin{array}{l}\text { Histology and immunohistochemistry, } \\
\text { Gene expression, Histological analysis }\end{array}$ \\
\hline LiY & $\begin{array}{l}\text { J Cell } \\
\text { Biochem }\end{array}$ & 2019 & C57BL/6 mice & $\begin{array}{l}\text { Bone } \\
\text { fracture }\end{array}$ & $\begin{array}{l}\text { In-vitro and } \\
\text { in-vivo }\end{array}$ & $\begin{array}{l}\text { In-vitro: ADSCs and } \\
\text { M } \varphi \text { s cell contract } \\
\text { co-culture; } \\
\text { In-vivo (a cylindrical } \\
\text { bone defect model): IL } \\
\text { injection of ADSCs }\end{array}$ & / & $\begin{array}{l}\text { Immunohistochemistry, Western-blot } \\
\text { analysis, RT-PCR, Enzyme-linked } \\
\text { immunosorbent assay, micro-CT }\end{array}$ \\
\hline Shen $\mathrm{H}$ & J Orthop Res & 2020 & $\begin{array}{l}\text { Scleraxis-GFP } \\
\text { tendon reporter } \\
\text { mice or NF-kB- } \\
\text { GFP-luciferase } \\
\text { transgenic reporter } \\
\text { mice-ADSCs } \\
\text { Wild type FVB/NJ } \\
\text { (FVB) -M } \varphi s\end{array}$ & $\begin{array}{l}\text { Tendon } \\
\text { injury }\end{array}$ & $\begin{array}{l}\text { In-vitro and } \\
\text { in-vivo }\end{array}$ & $\begin{array}{l}\text { In-vitro: Exos and } \mathrm{M} \varphi \mathrm{S} \\
\text { co-culture; } \\
\text { In-vivo (NGL mouse } \\
\text { model of Achilles } \\
\text { tendon injury and } \\
\text { repair): collagen sheet } \\
\text { loaded with EVs from } \\
\text { naÃ̄ve ASCs or } \\
\text { IFN } \gamma \text {-primed ASCs }\end{array}$ & $\begin{array}{l}\text { ADSCs intrinsic bio-activation: ADSCs were } \\
\text { cultured in an EV collection medium ( } 2 \% \\
\text { EV-free FBS in } \alpha \text {-MEM) for } 48 \mathrm{~h} \text {. CM from ASC } \\
\text { culture ( } 150 \mathrm{ml} \text { from } 2.5 \mathrm{E}+07 \text { cells per } \\
\text { isolation) with or without IFN } \gamma \text { pre-treatment } \\
\text { was collected and centrifuged at } 500 \mathrm{~g} \text { for } \\
10 \text { min and } 10,000 \mathrm{~g} \text { for } 30 \text { min at } 4{ }^{\circ} \mathrm{C} \text { to } \\
\text { remove large vesicles. After passing through a } \\
0.22 \mu \mathrm{m} \text { filter, the medium was further } \\
\text { centrifuged at } 100,000 \mathrm{~g} \text { for } 90 \text { min at } 4^{\circ} \mathrm{C} \text {. }\end{array}$ & $\begin{array}{l}\text { M } \varphi \text { s assays, NF-kB-Luciferase } \\
\text { Imaging in-vivo, RT-PCR, Histology }\end{array}$ \\
\hline
\end{tabular}

Both the methodology employed and the results obtained by each article are represented in this table. BMSCs, bone marrow stem cells; ADSCs, adipose tissue derived stem cells; M microparticles; EVs, extracellular vesicles; CM, conditioned medium; IA, intra-articularly; IL, intralesional; IV, intravenous; LMs, lipid mediators; EEMs, exosome-educated macrophages; LPS, lipopolysaccharide. 
$1 \times 10^{6}$ human BMSCs, $1 \times 10^{6} \mathrm{CD}_{1} 4^{+} \mathrm{M} \varphi \mathrm{s}, 1 \times 10^{6}$ exosomeeducated $\mathrm{M} \varphi \mathrm{s}$, or Hanks balanced saline solution (used as the injured control) to the surgical sites; the contralateral intact Achilles tendon without any treatment was used as a control (Chamberlain et al., 2019). In Shen et al. (2020) study, EVs produced by IFN- $\gamma$-primed and non-primed mouse ADSC were used to treat with $\mathrm{M} \varphi$ s to evaluate the impact of EVs on the $\mathrm{M} \varphi \mathrm{s}$ inflammatory response. And EV collection medium and EV-free $\mathrm{CM}$ were used as controls in the in vitro experiment. In Shen et al. (2020) in vivo experiment, collagen sheet loaded with EVs was applied around the repair sites, and the collagen sheet only was set as a control group. Shi et al. (2019) placed fibrin glue containing BMSC-EVs in the window defect of patellar tendon. The fibrin glue alone and non-surgical rats were designed as control groups.

In Lo Sicco et al. (2017) study, ADSC-derived EVs and PBS were intramuscularly injected into an injured TA muscle as experimental and control groups, respectively.

No target disease was mentioned in Hyvarinen et al. (2018) and Pacienza et al. (2019) studies. M $\varphi$ s cocultured with MSCs and MSC-EVs served as experimental variables in Hyvarinen et al. (2018) study, and $\mathrm{M} \varphi$ s served as the control group (Hyvarinen et al., 2018). In Pacienza et al. (2019) study, LPS-stimulated M $\varphi$ s treated with BMSC-derived exosomes served as the experimental group, and the three control groups were $\mathrm{M} \varphi$ s treated with complete medium alone, LPS, and LPS plus dexamethasone. In Pacienza et al. (2019) in vivo experiment, LPS alone or in combination with exosomes $\left(\sim 5 \times 10^{9}\right.$ vesicles $)$ was injected into mice through tail vein, respectively. Control group was injected with saline (Pacienza et al., 2019). Detailed results are listed in Table 3.

\section{Laboratory Effects and Proposed Mechanisms}

The bone fracture-related studies showed that femoral bone formation and bone volume all increased after ADSC injection. The increase in osteoblasts after ADSC injection was accompanied by increases in $\mathrm{CD} 206^{+}, \mathrm{CD}^{+} 8^{+}, \mathrm{CD} 11 \mathrm{~b}^{+}$, and $\mathrm{F} 4 / 80^{+}$cells, which represented a typical M2 surface phenotype. Meanwhile, the transcript and protein expression of Arg-1, M2 marker genes, were also up-regulated (Pacienza et al., 2019). Two OA-related studies reported that bone volume, cartilage thickness, hyaline cartilage formation, migration and proliferation of chondrocytes, and matrix synthesis were increased by BMSC-derived exosomes (Cosenza et al., 2017; Zhang et al., 2018). The therapeutic effect of anti-inflammation on $\mathrm{OA}$ was in line with a decrease in $\mathrm{M} 1 \mathrm{M} \varphi \mathrm{s}\left(\mathrm{F} 4 / 80^{+}, \mathrm{CD}^{+} 6^{+}\right.$, $\left.\mathrm{MHCII}^{+}, \mathrm{CD}_{4}{ }^{+}\right), \mathrm{IL}-1 \beta$, and tumor necrosis factor $\alpha$ (TNF- $\alpha$ ), as well as increases in chondrocytes, M2 M $\varphi$ s $\left(\mathrm{CD}_{163^{+}}\right)$, and IL-10 (Cosenza et al., 2017; Zhang et al., 2018). Moreover, BMSC-derived exosomes increased type II collagen deposition, and decreased type I collagen in cartilage was reported by Zhang et al. (2018) Such protective effects on chondrocytes might be attributed to the increase in Survivin, Bcl-2, and FGF-2 by BMSC-derived exosomes administration.

Lo Sicco et al. (2017) reported that ADSC-derived EVs were internalized in $\mathrm{M} \varphi s$ at the muscle injury site, which could promote myofiber regeneration. Interestingly, a dynamic change of $\mathrm{M} \varphi s$ subpopulation was observed after transplantation of ADSC-derived EVs. ADSC-derived EVs increased M1 M $\varphi s$ $\left(\mathrm{Ly}_{6 \mathrm{C}}+\mathrm{CD} 11 \mathrm{~b}^{+}, \mathrm{CD} 40^{+}, \mathrm{CD}^{+} 6^{+}\right)$at $24 \mathrm{~h}$ post-treatment and increased $\mathrm{M} 2 \mathrm{M} \varphi \mathrm{s}\left(\mathrm{CD} 206^{+}, \mathrm{CD}^{+} 1^{+}, \mathrm{CD}^{+} 6^{+}\right)$at $72 \mathrm{~h}$ post-treatment.

Extended results could be concluded from three tendon injury-related studies (Chamberlain et al., 2019; Shi et al., 2019; Shen et al., 2020). The shift of $\mathrm{M} \varphi$ s from M1 to M2 showed consistent variation to the increase in ultimate stress, Young's modulus (Chamberlain et al., 2019), NF-кB activity (Shen et al., 2020), fiber alignment score, tendon matrix formation, tenogenesis, and tendon cell proliferation (Shi et al., 2019) and the decrease in type I/type III collagen ratio (Chamberlain et al., 2019), gap-rupture rate (Shen et al., 2020), and tendon cell apoptosis (Shi et al., 2019) by BMSC-derived or ADSC-derived exosome administration.

\section{DISCUSSION}

Nowadays, it has been emphatically contended that all newly presented clinical interventions should start with and end with a systematic review, or even meta-analysis (Clarke et al., 2007). Although the therapeutic effects of MSCs via paracrine factors have been demonstrated in many pre-clinical investigations, the substantial clinical evidence in beneficial effects of MSCs in musculoskeletal diseases is not adequately investigated (Regenberg et al., 2009; Lukomska et al., 2019). This systematic review aims to analyze the impact of MSC and MSC-derived EVs on $\mathrm{M} \varphi s$ in the treatment of musculoskeletal diseases. According to the outcomes of the included studies, MSCs could promote musculoskeletal tissue repair or healing via their paracrine regulation on $\mathrm{M} \varphi$ s.

\section{Interactions of Predominant $\mathbf{M} \varphi$ s With MSC-EVs}

$\mathrm{M} \varphi s$ are predominant myeloid cells that chronologically accumulate in musculoskeletal tissue at the onset of injuryinduced inflammation and exhibit regulatory activity at all stages of the healing process (Tidball, 2011; Varol et al., 2015). Therefore, $\mathrm{M} \varphi$ s are potent triggers for tissue healing processes, including cell recruitment, proliferation, and remodeling (Artlett, 2013).

Growing evidence has demonstrated that the phenotypic switch of $\mathrm{M} \varphi$ s is critical in MSC-mediated tissue regeneration, which is presented in Figure 3. Moreover, M1 M $\varphi$-released proinflammatory cytokines enhanced the migratory capacity of MSCs that facilitates the accessibility of exogenous MSCs toward the injured site. Then, the attracted MSCs would regulate $\mathrm{M} \varphi$ phenotypes into M2 via paracrine effect to facilitate the tissue remodeling at a later stage (Le Blanc and Mougiakakos, 2012; Maxson et al., 2012; Shi et al., 2012; Bernardo and Fibbe, 2013; Ma et al., 2014). Interestingly, the secretomes of MSCs, such as EVs or exosomes, were also altered by $\mathrm{M} 1 \mathrm{M} \varphi$ that boosts the therapeutic effect of MSCs, so-called primed MSCs (Aktas et al., 2017; Saldana et al., 2019). 
TABLE 3 | Evaluations and results list of selected studies in which the therapeutic potential of the administration of MSCs for the treatment of musculoskeletal diseases.

\begin{tabular}{|c|c|c|c|c|c|c|c|}
\hline $\begin{array}{l}\text { Target } \\
\text { disease }\end{array}$ & References & Variables & Controls & Laboratory effects & Proposed mechanisms & Conclusions & $\begin{array}{l}\text { Research } \\
\text { implications }\end{array}$ \\
\hline \multirow[t]{2}{*}{$\begin{array}{l}\text { Bone } \\
\text { fracture }\end{array}$} & $\begin{array}{l}\text { Chang et al., } \\
2015\end{array}$ & $\begin{array}{l}\text { Seeding BM M } \varphi \text { s first. Then } \\
\text { placing primary or apoptotic } \\
\text { BMSCs. } \\
\text { Additional validation: IL-6 } \\
\text { KO mice. }\end{array}$ & $\begin{array}{l}\text { M } \varphi \text { s cultured alone, } \\
\text { apoptotic BMSCs } \\
\text { cultured alone, and } \\
\text { BMSCs cultured alone. }\end{array}$ & $\begin{array}{l}\uparrow \text { BMSCs migration } \\
\uparrow \text { BMSCs proliferation }\end{array}$ & $\begin{array}{l}\text { } \text { IL-6 proteins and mRNA } \\
\text { ! IL-6/gp130/STAT3 pathway }\end{array}$ & $\begin{array}{l}\text { BMSCs are the main } \\
\text { contributing cells of } \\
\text { juxtacrine IL-6 production. } \\
\text { Juxtacrine cultures } \\
\text { accelerated BMSCs } \\
\text { migration and numbers. }\end{array}$ & $\begin{array}{l}\text { Increase the } \\
\text { understanding of } \mathrm{M} \varphi \mathrm{S} \\
\text { in bone formation. }\end{array}$ \\
\hline & $\begin{array}{l}\text { Li Y. et al., } \\
2019\end{array}$ & $\begin{array}{l}\text { ADSCs and BM M } \varphi \text { s co-culture } \\
\text { system; } \\
\text { ADSCs locally injection. }\end{array}$ & Untreated control mice & $\begin{array}{l}\uparrow \text { femoral bone formation } \\
\uparrow \text { femoral bone volume }\end{array}$ & $\begin{array}{l}\uparrow \text { osteoblasts } \\
\uparrow \text { CD206+ cells } \\
\uparrow \text { CD68+ cells } \\
\downarrow \text { iNOS }+ \text { cells } \\
\uparrow \text { CD11b+ F4/80+ cells } \\
\uparrow \text { IL-1r } \alpha \text { proteins } \\
\downarrow \text { TNF- } \alpha \text { proteins and mRNA } \\
\downarrow \text { iNOS proteins and mRNA } \\
\uparrow \text { Arg- } 1 \text { proteins and mRNA } \\
\uparrow \text { MR proteins and mRNA } \\
\uparrow \text { Runx- } 2 \text { and osterix and OPG and ALP } \\
\text { genes } \\
\downarrow \text { RANKL genes }\end{array}$ & $\begin{array}{l}\text { ADSCs and M } \varphi s \text { can } \\
\text { synergistically contribute to } \\
\text { bone repair through mutual } \\
\text { regulation of their } \\
\text { differentiation and cytokine } \\
\text { secretion. }\end{array}$ & $\begin{array}{l}\text { The interactions } \\
\text { between ADSCs and } \\
\text { BM M } \varphi s \text { could be a } \\
\text { promising therapeutic } \\
\text { strategy in the } \\
\text { rehabilitation of bone } \\
\text { damage. }\end{array}$ \\
\hline \multirow[t]{2}{*}{ Osteoarthritis } & $\begin{array}{l}\text { Cosenza } \\
\text { et al., } 2017\end{array}$ & $\begin{array}{l}\text { Mediums of OA like } \\
\text { chondrocytes model were } \\
\text { replaced by medium containing } \\
\text { MPs, Exos, BMSCs-CM or } \\
\text { BMSCs (transwell); } \\
\text { BMSCs, MPs or Exos } \\
\text { intra-articularly injection. }\end{array}$ & OA control mice & $\begin{array}{l}\text { Restore the anabolic equilibrium } \\
\downarrow \text { apoptotic chondrocytes } \\
\downarrow \text { macrophage activation } \\
\uparrow \text { bone volume, cartilage } \\
\text { degradation (surface/volume } \\
\text { ratio) and thickness }\end{array}$ & $\begin{array}{l}\downarrow \text { MMP-13, ADAMTS5, iNOS genes } \\
\uparrow \text { ACAN, COL2B, COL1 genes } \\
\downarrow \text { F4/80+ cells } \\
\downarrow \text { CD86, MHCII or CD } 40 \text { markers } \\
\downarrow \text { TNF- } \alpha \text { proteins } \\
\uparrow \text { IL-10 proteins }\end{array}$ & $\begin{array}{l}\text { Exos were more efficient } \\
\text { than MPs and BMSCs in } \\
\text { chondroprotective and } \\
\text { anti-inflammatory function. }\end{array}$ & $\begin{array}{l}\text { MPs and Exos help to } \\
\text { promote re-establish } \\
\text { chondrocyte } \\
\text { homeostatic state. }\end{array}$ \\
\hline & $\begin{array}{l}\text { Zhang et al., } \\
2018\end{array}$ & Intra-articular injection of Exos. & $\begin{array}{l}\text { Intra-articular injection } \\
\text { of PBS } \\
\end{array}$ & $\begin{array}{l}\uparrow \text { neotissue formation and ECM } \\
\text { deposition of s-GAG } \\
\uparrow \text { Wakitani score } \\
\uparrow \text { surface regularity } \\
\uparrow \text { hyaline cartilage formation } \\
\uparrow \text { percentage areal deposition of } \\
\text { type II collagen } \\
\downarrow \text { percentage areal deposition of } \\
\text { type I collagen } \\
\uparrow \text { chondrocyte migration, } \\
\text { proliferation and matrix synthesis } \\
\uparrow \text { metabolic activity }\end{array}$ & $\begin{array}{l}\uparrow \text { chondrocytic cells } \\
\downarrow \text { PCNA+ cells } \\
\uparrow \text { CD } 163+\text { cells } \\
\downarrow \text { CD86+ cells } \\
\downarrow \text { LL- } 1 \beta \text { and TNF- } \alpha \\
\uparrow \text { Survivin, Bcl- } 2 \text {, FGF- } 2 \text { mRNA } \\
\text { ! AKT and ERK pathways } \\
\end{array}$ & $\begin{array}{l}\text { Exos mediate cartilage } \\
\text { repair by mounting a } \\
\text { coordinated, multi-faceted } \\
\text { response of enhancing } \\
\text { proliferation, migration and } \\
\text { matrix synthesis, attenuating } \\
\text { apoptosis and modulating } \\
\text { immune reactivity. }\end{array}$ & $\begin{array}{l}\text { Exso could be providec } \\
\text { as a cell-free MSC } \\
\text { therapeutic. }\end{array}$ \\
\hline $\begin{array}{l}\text { Muscle } \\
\text { damage }\end{array}$ & $\begin{array}{l}\text { Lo Sicco } \\
\text { et al., } 2017\end{array}$ & $\begin{array}{l}\text { EVs-M } \varphi \text { s co-culture; } \\
\text { EVs were intramuscularly } \\
\text { administered into muscle. }\end{array}$ & $\begin{array}{l}\text { PBS were } \\
\text { intramuscularly } \\
\text { administered into } \\
\text { muscle }\end{array}$ & $\begin{array}{l}\uparrow \text { internalization of EVs in M } \varphi \text { s } \\
\uparrow \mathrm{M} \varphi \text { s proliferation } \\
\downarrow \mathrm{M} 1 / \mathrm{M} 2 \\
\downarrow \text { mononucleated myoblasts } \\
\uparrow \text { fibers containing nuclei } \geq 2 \\
\end{array}$ & $\begin{array}{l}\uparrow \text { Ly6C, CD11b, CD40, CD86 (post-treat } \\
24 \mathrm{~h} \text { ) } \\
\uparrow \text { CD206, CD51, CD36 (post-treat 72h) } \\
\downarrow \text { CD11b, CD86 (post-treat 72h) } \\
\downarrow \text { IL-6/L-10 } \\
\uparrow \text { Arg-1, Ym-1markers } \\
\downarrow \text { Nos-2 markers } \\
\uparrow \text { CD206+ cells } \\
\downarrow \text { Ly6C+ cells } \\
\uparrow \text { MCP-1 } \\
\uparrow \text { Pax-7, MyoD genes (activated satellite } \\
\text { cells); eMyhc gene (regenerating fibers) }\end{array}$ & $\begin{array}{l}\text { EVs co-cultured with } \\
\text { responding BM-derived } \\
\text { M } \varphi \text { s, shifting the balance } \\
\text { toward a M2 phenotype. }\end{array}$ & $\begin{array}{l}\text { Establish an alternative } \\
\text { cell-free approach of } \\
\text { EVs for the induction of } \\
\text { regenerative } \\
\text { processes. }\end{array}$ \\
\hline
\end{tabular}




\begin{tabular}{|c|c|c|c|c|c|c|c|}
\hline $\begin{array}{l}\text { Target } \\
\text { disease }\end{array}$ & References & Variables & Controls & Laboratory effects & Proposed mechanisms & Conclusions & $\begin{array}{l}\text { Research } \\
\text { implications }\end{array}$ \\
\hline \multirow[t]{3}{*}{ Tendon injury } & $\begin{array}{l}\text { Chamberlain } \\
\text { et al., } 2019\end{array}$ & $\begin{array}{l}\text { EVs-M } \varphi \text { S co-culture; } \\
\text { BMSCs, CD14+M } 9 \text { s or EEMs } \\
\text { locally injection. }\end{array}$ & $\begin{array}{l}\text { M } \varphi \text { s controls were } \\
\text { treated with PBS; } \\
\text { Contralateral controls }\end{array}$ & $\begin{array}{l}\uparrow \text { EVs educated M } \varphi s \\
\uparrow \text { ultimate stress and Young's } \\
\text { modulus } \\
\downarrow \mathrm{M} 1 / \mathrm{M} 2 \text { ratio } \\
\downarrow \text { type I collagen } \\
\downarrow \text { type I/type III collagen ratio }\end{array}$ & $\begin{array}{l}\uparrow \text { CD206 mean fluorescence intensity and } \\
\text { cells } \\
\uparrow \text { PD-L1 mean fluorescence intensity and } \\
\text { cells } \\
\uparrow \mathrm{M} 2 \mathrm{M} \varphi \mathrm{s} \\
\downarrow \mathrm{M} 1 \mathrm{M} \varphi \mathrm{S} \\
\uparrow \text { endothelial cells }\end{array}$ & $\begin{array}{l}\text { EVs-educated } \mathrm{M} \varphi \mathrm{s} \\
\text { treatments improve } \\
\text { mechanical properties for } \\
\text { tendon function as shown } \\
\text { by reduce endogenous } \\
\mathrm{M} 1 / \mathrm{M} 2 \text { ratio indicating less } \\
\text { inflammation. }\end{array}$ & $\begin{array}{l}\text { EEMs treatment } \\
\text { provides a novel } \\
\text { strategy in } \\
\text { musculoskeletal } \\
\text { injuries. }\end{array}$ \\
\hline & $\begin{array}{l}\text { Shen et al., } \\
2020\end{array}$ & $\begin{array}{l}\text { EVs-M } \varphi \text { s co-culture; } \\
\text { Collagen sheet loaded with EVs } \\
\text { was applied around the } \\
\text { repair site. }\end{array}$ & $\begin{array}{l}\text { EVs collection medium } \\
\text { and EV-free } \\
\text { conditioned medium } \\
\text { controls; } \\
\text { Collagen sheet only } \\
\text { control. } \\
\text { IL-1 (EVs from } \\
\text { IFN } \text {-primed ASCs) }\end{array}$ & $\begin{array}{l}\uparrow N F \text {-kB activity } \\
\uparrow / \downarrow \text { Matrix gene expression } \\
\downarrow \text { gap-rupture rate }\end{array}$ & $\begin{array}{l}\downarrow \mathrm{IL}-1 \text { gene (only EVs from IFN } \gamma \text {-primed } \\
\text { ASCs) } \\
\uparrow \text { IFN } \gamma \text { gene (only EVs from IFN } \gamma \text {-primed } \\
\text { ASCs) } \\
\uparrow \mathrm{MMP}-1 \text {, Sox- } 9 \text { genes } \\
\uparrow \mathrm{Col}-1 \alpha 1 \text {, Col-2 } 2 \alpha 1 \text { and Col- } 3 \alpha 1 \text { genes } \\
\text { (only EVs from IFN } \gamma \text {-primed ASCs) } \\
\uparrow \text { collagen staining (only EVs from } \\
\text { IFN } \gamma \text {-primed ASCs) }\end{array}$ & $\begin{array}{l}\text { EVs from ASCs can shift the } \\
\text { M } \varphi \text { s phenotypic response } \\
\text { to tendon injury from a } \\
\text { default M1 to a M2 } \\
\text { phenotype. }\end{array}$ & $\begin{array}{l}\text { EVs could be a new } \\
\text { cell-free therapy, for } \\
\text { tendon repair with the } \\
\text { potential for improved } \\
\text { therapeutic efficacy } \\
\text { and safety. }\end{array}$ \\
\hline & $\begin{array}{l}\text { Shi et al., } \\
2019\end{array}$ & $\begin{array}{l}\text { Fibrin glue containing EVs was } \\
\text { placed in the window defect }\end{array}$ & $\begin{array}{l}\text { Fibrin glue alone and } \\
\text { untreated controls }\end{array}$ & $\begin{array}{l}\uparrow \text { Fiber alignment score } \\
\uparrow \text { anti-inflammatory response } \\
\uparrow \text { tendon matrix formation } \\
\uparrow \text { tenogenesis } \\
\downarrow \text { tendon cell apoptosis } \\
\uparrow \text { tendon cell proliferation }\end{array}$ & $\begin{array}{l}\uparrow \text { CD163 marker } \\
\uparrow \text { IL-4, IL-10 mRNA and + cells } \\
\downarrow \text { IFN }, \text { IL- } 1 \beta, \text { IL-6, CCR7 + cells } \\
\uparrow \text { SCX, TNMD, Col- } 1 \alpha 1 \text {, Col- } 3 \alpha 1 \text { genes } \\
\uparrow \text { CD146+ cells } \\
\downarrow \text { cleaved caspase } 3 \text { signals }\end{array}$ & $\begin{array}{l}\text { EVs derived from BMSCs } \\
\text { can help to improve the } \\
\text { quality of tendon healing by } \\
\text { promoting an } \\
\text { anti-inflammatory } \\
\text { environment. }\end{array}$ & $\begin{array}{l}\text { These findings provide } \\
\text { a basis for the potential } \\
\text { clinical use of } \\
\text { BMSC-EVs in tendon } \\
\text { repair. }\end{array}$ \\
\hline \multirow[t]{2}{*}{ None } & $\begin{array}{l}\text { Hyvarinen } \\
\text { et al., } 2018\end{array}$ & $\begin{array}{l}\text { MSCs-M } \varphi \text { S coculture; } \\
\text { MSC-EVs-M } \varphi \text { s coculture }\end{array}$ & $\mathrm{M} \varphi s$ only control & $\begin{array}{l}\downarrow \text { FRI of CD163 } \\
\downarrow \text { cytokine levels of Mreg-CM } \\
\uparrow \text { LMs level and pathway } \\
\text { markers } \\
\uparrow \text { phagocytic ability }\end{array}$ & $\begin{array}{l}\downarrow \text { CD163+ cells } \\
\downarrow \text { IL-10, IL-22, IL-23, TNF- } \alpha \text { proteins } \\
\uparrow \text { arachidonic acid-derived PGE2, } \\
15 \text {-HETE, docosahexaenoic acid-derived } \\
17-\text { HDHA } \\
\uparrow \text { CD206 Mregs and receptors }\end{array}$ & $\begin{array}{l}\text { Both MSCs and MSC-EVs } \\
\text { decrease IL-23 and IL-22 } \\
\text { while increasing PGE2 } \\
\text { production. }\end{array}$ & $\begin{array}{l}\text { MSC-EVs may } \\
\text { potentiate } \\
\text { tolerance-promoting } \\
\text { proresolving phenotype } \\
\text { of human Mregs. }\end{array}$ \\
\hline & $\begin{array}{l}\text { Pacienza } \\
\text { et al., } 2019\end{array}$ & $\begin{array}{l}\text { LPS in combination with } \\
\text { Exos-M } \varphi \text { s coculture; } \\
\text { Tail vein injection of LPS }\end{array}$ & $\begin{array}{l}\text { FBS medium alone } \\
\text { control, containing LPS } \\
\text { control, and LPS plus } \\
\text { dexamethasone } \\
\text { control; } \\
\text { Tail vein injection of } \\
\text { saline control }\end{array}$ & $\begin{array}{l}\uparrow \text { anti-inflammatory activity } \\
\uparrow \text { predictive efficacy }\end{array}$ & $\begin{array}{l}\downarrow \text { IL-6, IL- } 1 \beta \text { levels } \\
\downarrow \text { iNOS mRNA }\end{array}$ & $\begin{array}{l}\text { Exos could suppress } \\
\text { LPS-induced inflammation. }\end{array}$ & $\begin{array}{l}\text { In-vitro } \mathrm{M} \varphi \text { s assay } \\
\text { predicts the in-vivo } \\
\text { anti-inflammatory } \\
\text { potential of Exos }\end{array}$ \\
\hline
\end{tabular}

Both the methodology employed and the results obtained by each article are represented in this table. Apoptotic BMSCs (exposed to UV light treatment for 30 min); !, activation; KO, knockout; TNF- $\alpha$, tumor necrosis factor- $\alpha$; RANKL, receptor activator of nuclear factor $\mathrm{KB}$ ligand; iNOS, inducible nitric oxide synthase; MR, mannose receptor; Arg-1, Antibodies against arginase 1; Runx-2, runt-related transcription factor 2; OPG, osteoprotegerin; ALP, alkaline phosphatase; Mregs, regulatory macrophages; MPs, microparticles; Exos, exosomes; EVs, extracellular vesicles; EEMs, exosome-educated macrophages; OA, osteoarthritis; ECM, extracellular matrix; FRI, fluorescence intensity; LMs, lipid mediators; LPS, lipopolysaccharide. 
The cross-talk between $\mathrm{M} \varphi$ s and MSC-derived EVs regulates a shift in M $\varphi$ s subtypes from M1 into M2 (Galli et al., 2011). An increasing number of musculoskeletal tissue injury models showed that $\mathrm{M} \varphi$ s phenotypic alteration mediated MSC-based therapy (Lo Sicco et al., 2017; Chu et al., 2019). M1 M $\varphi$ s promote recruitment of inflammatory immune cells and release extracellular matrix (ECM) degrading proteins to allow quick migration to inflamed sites. As the $\mathrm{M} \varphi$ s shift to M2 subtypes, the release of proinflammatory cytokines is inhibited, angiogenesis is stimulated, and fibroblasts are activated to produce and restore more ECM. Also, $\mathrm{M} \varphi$ s induced MSCs into a motile phenotype with increased secretion of IL-6 and IL-10, which benefit MSCs to migrate to injury site (Anton et al., 2012; Wolfe et al., 2016). Typically, MSC-EVs impact the maturation of $\mathrm{M} \varphi$ s by decreasing the expression levels of IL-12 and TNF$\alpha$ and increasing IL- 6 and IL-10 in $\mathrm{M} \varphi$ s (Kim and Hematti, 2009; Cosenza et al., 2017; Lo Sicco et al., 2017; Hyvarinen et al., 2018; Shi et al., 2019). PGE 2 and TNF- $\alpha$ inducible gene 6 (TSG-6) embedded in MSC-EVs can promote M2 polarization in inflammatory microenvironment (Nemeth et al., 2009; Maggini et al., 2010; Melief et al., 2013b). EVs, which were released from proinflammatory cytokines-activated MSCs, could enhance anti-inflammatory properties to suppress MHC class II and CD86 signaling in LPS-stimulated M $\varphi$ s (Melief et al., 2013a,b; Cho et al., 2014). Lo Sicco et al. (2017) and Chamberlain et al. (2019) reported the MSC-EVs change the M1-to-M2 M $\varphi$ s ratio. And Lo Sicco et al. (2017) demonstrated that MSC-EVs could be efficiently internalized by responding cells, inducing an increase in their proliferation rate, and shifting the balance toward an alternatively anti-inflammatory M2 phenotype. M2 $\mathrm{M} \varphi$ s phenotype could be commonly associated with the secretion of the anti-inflammatory cytokine IL-10 and scavenger receptors CD206 and CD163 (Sica and Mantovani, 2012; Mantovani et al., 2013).

In this review, we found consistent results suggesting that an M2 phenotype could be induced from M1 M $\varphi$ s upon coculture with MSCs, MSC-EVs, and CM. The enrichment of M1 M $\varphi$ s appears at early phases (1-3 days) during bone remodeling (Chang et al., 2015; Li Y. et al., 2019), muscle regeneration (Lo Sicco et al., 2017), and tendon healing (Chamberlain et al., 2019; Harvey et al., 2019; Shi et al., 2019; Shen et al., 2020) and is later replaced by $\mathrm{M} 2 \mathrm{M} \varphi \mathrm{s}$ (4-7 days). As $\mathrm{M} \varphi$ polarization and tissue repair by MSC-EVs are highly associated, MSC-EVsmediated $\mathrm{M} \varphi$ s phenotypic transformation must play a significant role during tissue healing. However, the molecular action of MSC-EVs in such $\mathrm{M} \varphi$ polarization and tissue regeneration needs further investigation (Chen et al., 2008; Rodero and Khosrotehrani, 2010).

Although studies have provided evidence of immunosuppressive effects of MSCs in clinical trials for graft-vs.-host disease and Crohn disease (Godoy et al., 2019), the transplanted MSCs have not been proven in the persistence after injection and the contribution in tissue regeneration (Pittenger, 2009; Parekkadan and Milwid, 2010; Caplan and Correa, 2011). It is likely that the main immunosuppressive effects of MSCs resulted from paracrine regulation through secreted mediators, including EVs (Raposo and Stoorvogel, 2013). The immune modulation effect of MSC has been generalized as

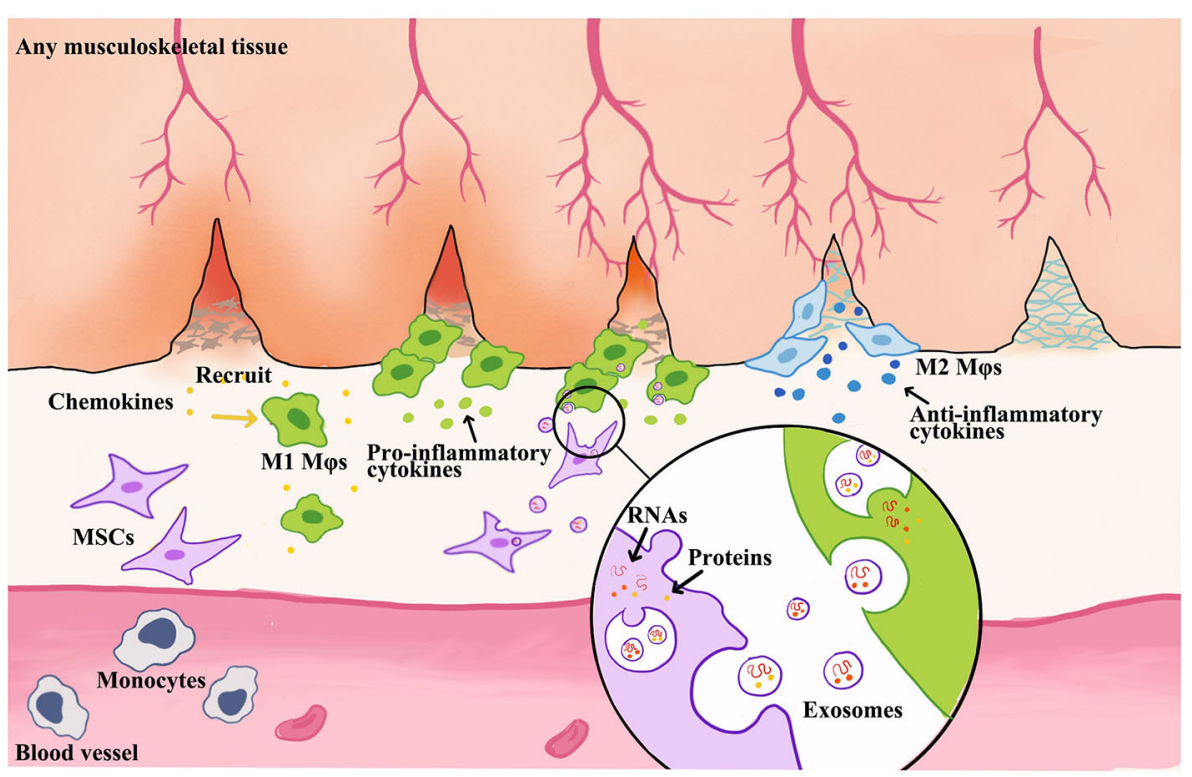

FIGURE 3 | Schematic illustration of MSC-derived exosome-guided macrophage reprogramming. MSC-derived exosomes can induce a conversion of M1 to M2 M $\varphi$ S and accelerate musculoskeletal tissue healing. M $\varphi$ s could be activated by inflammatory chemokines and then to produce proinflammatory factors. This creates a feedback loop whereby proinflammatory cytokines produced by M $\varphi$ s stimulate MSC to produce immune modulators, such as exosomes or EVs. Therefore, the formation of exosomes begins with membrane invagination in the form of endosomes, leading to the development of the early endosomes. Upon maturation, the endosomes become multivesicular endosomes, which release their contents in the form of exosomes. 
the inhibition of both innate and adaptive immunity and also derives inflammatory, autoimmune, and infectious disease pathology (Le Blanc and Mougiakakos, 2012; English, 2013). However, increasing analysis in animal models of inflammation demonstrated that MSC-EVs suppressed immune response through the transfer of RNAs and protein (Cantaluppi et al., 2012; Arslan et al., 2013). The inflammatory signals are essential to initiate and maintain the MSC- or EV-mediated tissue repair process; afterward, MSC-derived EVs could manipulate the niche by switching $\mathrm{M} \varphi$ phenotype to facilitate tissue repair.

\section{Functional MSC-EVs Cargo and Boosting Approaches}

Recently, the use of MSC-based therapies has emerged. The therapeutic benefits of MSC transplantation have been attributed into two types, EVs and soluble factors. Soluble components include a wide variety of secreted chemokines, growth factors, and hormones with immunomodulatory activity. For example, $\mathrm{PGE}_{2}$ and TGF- $\beta$ are vital mediators of anti-inflammatory in therapeutic therapy of MSCs (Yoo et al., 2013). And lots of anti-inflammatory proteins also represent tissue protection, such as TSG-6, which has been reported with healing ability by reducing the influx of neutrophils to the tissue injury site (Oh et al., 2010). The studies regarding MSC-derived EVs have grown exponentially since it has been recognized that EVs containing mRNA, miRNA, and protein could exchange intracellular information and act as sophisticated mediators of recipient cell behavior, particularly in immunomodulation (Wolfers et al., 2001; Valadi et al., 2007; Skog et al., 2008). MSCderived EVs contain not only more than 200 mRNA and 60 miRNA, but also more than 800 proteins (Bruno et al., 2009; Chen et al., 2010; Lai et al., 2012). These EV-derived proteins have been reported with an integral role in activating antiinflammatory responses and regulating the cascade of tissue healing process in various injury models (Lee et al., 2012; Zhang et al., 2018; Li et al., 2019).

It has been demonstrated that genetically modified MSCs possess great prosurvival, proangiogenic, and anti-inflammatory properties not only by the altering release of soluble proteins, but also EVs (Huang et al., 2013; Wang et al., 2016; Lou et al., 2017; Ma et al., 2017; Qu et al., 2017; Tao et al., 2017). MSCderived EVs are engineered at the cellular level under natural conditions, and it further highlighted the unique advantage of EV-based nanoplatforms for cargo delivery (Luan et al., 2017). For clinical applications, some advantages of MSC-derived EVs include easier injection, reduced $\mathrm{M} \varphi$ s phagocytosis and vascular occlusion (EL Andaloussi et al., 2013), innate biocompatibility, high physicochemical stability, high penetrability, and longdistance communication (Clayton et al., 2003; Ridder et al., 2014; Zomer et al., 2015).

Many strategies have been applied to modify EVs, including cell modification and direct EV modification (Armstrong and Perriman, 2016). Because EVs are secreted from cells, they can intrinsically express some lipids or cell adhesion molecules and ligands that naturally target certain types of recipient cells
(Luan et al., 2017). Undoubtedly, it was inevitable that genetic engineering has been used to modify EVs. Overexpression of mRNA or miRNA in cells could be assembled into EVs, which could be fused to target cells to introduce or inhibit gene expression (Kosaka et al., 2010; Akao et al., 2011; Ridder et al., 2014; Zomer et al., 2015). For a significant amount of time, researchers have explored non-native biomaterials to cells to augment therapeutic function (Armstrong et al., 2015; Correia Carreira et al., 2016). Therefore, biomaterials delivered to the membrane could also naturally be incorporated into budding EVs, while internalized material may be packaged into exosomes for secretion (Armstrong et al., 2017). Taking advantage of these methods allows cellular processes and cell engineering techniques to be specifically adapted to EV functionalization.

Because only a small fraction of material could be packaged into EVs, the efficiency issue results in a low-yielding ending. And besides the widely explored cancer cells, the yield of exosomes derived from MSCs is one of the major factors that limits the expansion of cell-free therapeutic productions (Phan et al., 2018). Functional EVs could be derived from native ECM (Huleihel et al., 2016; Du et al., 2017), and threedimensional environment for cell attachment and growth has been particularly attracted because it can mimic the ECM structure and function (Phan et al., 2018). Such structure has been reported with the effects of influencing EV secretion. For example, Tao et al. reported that Avitene Ultrafoam collagen hemostat caused the BMSCs to release 2-fold of exosomes compared to the plastic surface culture based on protein assay (Tao et al., 2017). Besides, a bioactive artificial ECM that was modified by adding molecules has been used to imitate native ECM mimicking structures and to improve yield of MSC exosomes by presenting specific functional ligands (Hao et al., 2017).

Moreover, an essential and urgent solution can provide an approach to improve the yield without sacrificing the functionality or with enhancing the efficacy simultaneously. Therefore, researchers tried to purify EVs, which could ensure that all modified sites or encapsulated species could be localized at the vesicle (Armstrong et al., 2017). As non-living entities, EVs have a major advantage over cells when they received membrane surface modification. It has been reported that excessive pressures, temperature, chemical induction, or hypoxia environment exposure could cause membrane disruption, vesicle aggregation, and surface protein denaturation (Smyth et al., 2014; Armstrong et al., 2017; Lo Sicco et al., 2017). Also, multivalent electrostatic interactions, receptorligand binding, and hydrophobic insertion have been commonly applied as methods of biological membrane modifications (Nakase and Futaki, 2015; Correia Carreira et al., 2016; Lee et al., 2016). In addition, electroporation, which is an alternative approach to EV active loading strategies, has been reported to transiently permeabilize the $\mathrm{EV}$ membrane to enhance the absorptivity of small molecules (Tian et al., 2014; Fuhrmann et al., 2015). Taken together, the engineered EVs will open up exciting opportunities in EV-based therapies 
by boosting therapeutic capability, which is beyond their native functions.

\section{STRENGTHS AND LIMITATIONS}

This systematic review poses several advantages compared to other attempts to summarize the experimental results of MSC-derived paracrine mediators for musculoskeletal diseases. First, the up-to-date literature search has been yielded by two widely used databases: PubMed and EMBASE. The search strategies included MeSH terms and other related terms. Therefore, we could identify a number of eligible studies, which might remain relatively unnoticed. Second, the quality of included studies and risk of bias, including publication bias, were assessed. Third, study heterogeneity had been explored to point out potential explanatory variables. Fourth, to standardize the spontaneous recovery in the control groups, we analyzed the variables and controls specifically. And studies without scientific controls have been excluded during full-text screening procedure.

There were several limitations to this study. The first limitation is the small number of included studies. The second limitation is that we could not standardize the effectiveness of $\mathrm{M} \varphi \mathrm{s}$ depletion among different studies. Moreover, the depletion is not permanent and, once subsided, could result in a reactive increase in $\mathrm{M} \varphi$ s numbers with unknown consequences. Third, these studies utilized different cell sources and delivery methods. Different types of animals were selected for in vivo studies. Fourth, the assessment methods also widely varied among studies; therefore, it was impossible to perform a quantitative analysis or a meta-analysis with the included studies.

\section{CONCLUSION}

This review demonstrated that MSC and MSC-EVs are authentic biomaterials to treat musculoskeletal problems. The broad therapeutic effect of MSC and MSC-EVs attribute to the

\section{REFERENCES}

Akao, Y., Iio, A., Itoh, T., Noguchi, S., Itoh, Y., Ohtsuki, Y., et al. (2011). Microvesicle-mediated RNA molecule delivery system using monocytes/macrophages. Mol. Ther. 19, 395-399. doi: 10.1038/mt.20 10.254

Aktas, E., Chamberlain, C. S., Saether, E. E., Duenwald-Kuehl, S. E., Kondratko-Mittnacht, J., Stitgen, M., et al. (2017). Immune modulation with primed mesenchymal stem cells delivered via biodegradable scaffold to repair an achilles tendon segmental defect. J. Orthop. Res. 35, 269-280. doi: $10.1002 /$ jor. 23258

Anderson, C. F., and Mosser, D. M. (2002). A novel phenotype for an activated macrophage: the type 2 activated macrophage. J. Leukoc. Biol. 72, 101-106.

Anton, K., Banerjee, D., and Glod, J. (2012). Macrophage-associated mesenchymal stem cells assume an activated, migratory, pro-inflammatory phenotype with increased IL-6 and CXCL10 secretion. PLOS ONE 7:e35036. doi: 10.1371/journal.pone.0035036 management of $\mathrm{M} \varphi$ polarization, at least in part. A further understanding in the molecular mechanism of how MSCs regulate $\mathrm{M} \varphi$ polarization will facilitate the development of bioengineering approach to boost the therapeutic capacity of MSCs and their clinical application. However, more preclinical studies are needed to understand how EVs and their subcomponent play a role in musculoskeletal tissue healing process.

\section{DATA AVAILABILITY STATEMENT}

All datasets generated for this study are included in the article/Supplementary Material.

\section{AUTHOR CONTRIBUTIONS}

HX: conception and design, manuscript writing, and data analysis and interpretation. C-WL: conception and design, financial support, and manuscript writing. Y-FW: manuscript writing. L-YS, Y-HW, ZW, and XZ: data analysis and interpretation. PY and OL: administrative support and final approval of manuscript. SH: revisions to scientific content of manuscripts. All authors contributed to the article and approved the submitted version.

\section{FUNDING}

This work was supported by MWLC Associate Member Programme, Ming Wai Lau Centre for Reparative Medicine of Karolinska Institute to OL; CUHK Research Committee Direct Grant for Research (Reference no. 2018.020) and Hong Kong Government Research Grant Council, General Research Fund (Reference no. 14104620) to CW-L.

\section{SUPPLEMENTARY MATERIAL}

The Supplementary Material for this article can be found online at: https://www.frontiersin.org/articles/10.3389/fbioe. 2020.587052/full\#supplementary-material

Armstrong, J. P., Holme, M. N., and Stevens, M. M. (2017). Re-engineering extracellular vesicles as smart nanoscale therapeutics. ACS Nano 11, 69-83. doi: 10.1021/acsnano.6b07607

Armstrong, J. P., and Perriman, A. W. (2016). Strategies for cell membrane functionalization. Exp. Biol. Med. 241, 1098-1106. doi: $10.1177 / 1535370216650291$

Armstrong, J. P. K., Shakur, R., Horne, J. P., Dickinson, S. C., Armstrong, C. T., Lau, K., et al. (2015). Artificial membrane-binding proteins stimulate oxygenation of stem cells during engineering of large cartilage tissue. Nat. Commun. 6:7405. doi: 10.1038/ncomms8405

Arslan, F., Lai, R. C., Smeets, M. B., Akeroyd, L., Choo, A., Aguor, E. N., et al. (2013). Mesenchymal stem cell-derived exosomes increase ATP levels, decrease oxidative stress and activate PI3K/Akt pathway to enhance myocardial viability and prevent adverse remodeling after myocardial ischemia/reperfusion injury. Stem Cell Res. 10, 301-312. doi: 10.1016/j.scr.2013.01.002

Artlett, C. M. (2013). Inflammasomes in wound healing and fibrosis. J. Pathol. 229, 157-167. doi: 10.1002/path.4116 
Bagno, L., Hatzistergos, K. E., Balkan, W., and Hare, J. M. (2018). Mesenchymal stem cell-based therapy for cardiovascular disease: progress and challenges. Mol. Ther. 26, 1610-1623. doi: 10.1016/j.ymthe.2018.05.009

Bernardo, M. E., and Fibbe, W. E. (2013). Mesenchymal stromal cells: sensors and switchers of inflammation. Cell Stem Cell 13, 392-402. doi: 10.1016/j.stem.2013.09.006

Bility, M. T., Cheng, L., Zhang, Z., Luan, Y., Li, F., Chi, L., et al. (2014). Hepatitis $B$ virus infection and immunopathogenesis in a humanized mouse model: induction of human-specific liver fibrosis and M2-like macrophages. PLoS Pathog. 10:e1004032. doi: 10.1371/journal.ppat.1004032

Bosurgi, L., Manfredi, A. A., and Rovere-Querini, P. (2011). Macrophages in injured skeletal muscle: a perpetuum mobile causing and limiting fibrosis, prompting or restricting resolution and regeneration. Front. Immunol. 2:62. doi: $10.3389 /$ fimmu. 2011.00062

Bruno, S., Grange, C., Collino, F., Deregibus, M. C., Cantaluppi, V., Biancone, L., et al. (2012). Microvesicles derived from mesenchymal stem cells enhance survival in a lethal model of acute kidney injury. PLoS ONE 7:e33115. doi: 10.1371/journal.pone.0033115

Bruno, S., Grange, C., Deregibus, M. C., Calogero, R. A., Saviozzi, S., Collino, F., et al. (2009). Mesenchymal stem cell-derived microvesicles protect against acute tubular injury. J. Am. Soc. Nephrol. 20, 1053-1067. doi: 10.1681/ASN.2008070798

Cantaluppi, V., Gatti, S., Medica, D., Figliolini, F., Bruno, S., Deregibus, M. C., et al. (2012). Microvesicles derived from endothelial progenitor cells protect the kidney from ischemia-reperfusion injury by microRNAdependent reprogramming of resident renal cells. Kidney Int. 82, 412-427. doi: $10.1038 / \mathrm{ki} .2012 .105$

Caplan, A. I. (1991). Mesenchymal stem cells. J. Orthop. Res. 9, 641-650. doi: 10.1002/jor.1100090504

Caplan, A. I., and Correa, D. (2011). The MSC: an injury drugstore. Cell Stem Cell 9, 11-15. doi: 10.1016/j.stem.2011.06.008

Carrero, R., Cerrada, I., Lledo, E., Dopazo, J., Garcia-Garcia, F., Rubio, M. P., et al. (2012). ILlbeta induces mesenchymal stem cells migration and leucocyte chemotaxis through NF-kappaB. Stem Cell Rev. Rep. 8, 905-916. doi: 10.1007/s12015-012-9364-9

Cha, J. M., Shin, E. K., Sung, J. H., Moon, G. J., Kim, E. H., Cho, Y. H., et al. (2018). Efficient scalable production of therapeutic microvesicles derived from human mesenchymal stem cells. Sci. Rep. 8:1171. doi: 10.1038/s41598-018-19211-6

Chamberlain, C. S., Clements, A. E. B., Kink, J. A., Choi, U., Baer, G. S., Halanski, M. A., et al. (2019). Extracellular vesicle-educated macrophages promote early achilles tendon healing. Stem Cells 37, 652-662. doi: 10.1002/stem.2988

Chang, J., Koh, A. J., Roca, H., and McCauley, L. K. (2015). Juxtacrine interaction of macrophages and bone marrow stromal cells induce interleukin- 6 signals and promote cell migration. Bone Res. 3:15014. doi: 10.1038/boneres.2015.14

Chen, L., Tredget, E. E., Wu, P. Y., and Wu, Y. (2008). Paracrine factors of mesenchymal stem cells recruit macrophages and endothelial lineage cells and enhance wound healing. PLoS ONE 3:e1886. doi: 10.1371/journal.pone.0001886

Chen, T. S., Lai, R. C., Lee, M. M., Choo, A. B., Lee, C. N., and Lim, S. K. (2010). Mesenchymal stem cell secretes microparticles enriched in pre-microRNAs. Nucleic Acids Res. 38, 215-224. doi: 10.1093/nar/gkp857

Cheng, L., Zhang, K., Wu, S., Cui, M., and Xu, T. (2017). Focus on mesenchymal stem cell-derived exosomes: opportunities and challenges in cell-free therapy. Stem Cells Int. 2017:6305295. doi: 10.1155/2017/6305295

Cheng, Y., and Schorey, J. S. (2013). Exosomes carrying mycobacterial antigens can protect mice against Mycobacterium tuberculosis infection. Eur. J. Immunol. 43, 3279-3290. doi: 10.1002/eji.201343727

Cho, D. I., Kim, M. R., Jeong, H. Y., Jeong, H. C., Jeong, M. H., Yoon, S. $\mathrm{H}$., et al. (2014). Mesenchymal stem cells reciprocally regulate the M1/M2 balance in mouse bone marrow-derived macrophages. Exp. Mol. Med. 46:e70. doi: 10.1038/emm.2013.135

Chu, S. Y., Chou, C. H., Huang, H. D., Yen, M. H., Hong, H. C., Chao, P. H., et al. (2019). Mechanical stretch induces hair regeneration through the alternative activation of macrophages. Nat. Commun. 10:1524. doi: 10.1038/s41467-019-09402-8

Clarke, M., Hopewell, S., and Chalmers, I. (2007). Reports of clinical trials should begin and end with up-to-date systematic reviews of other relevant evidence: a status report. J. R. Soc. Med. 100, 187-190. doi: 10.1177/014107680710011415
Clayton, A., Harris, C. L., Court, J., Mason, M. D., and Morgan, B. P. (2003). Antigen-presenting cell exosomes are protected from complement-mediated lysis by expression of CD55 and CD59. Eur. J. Immunol. 33, 522-531. doi: $10.1002 / \mathrm{immu} .200310028$

Correia Carreira, S., Armstrong, J. P., Seddon, A. M., Perriman, A. W., HartleyDavies, R., and Schwarzacher, W. (2016). Ultra-fast stem cell labelling using cationised magnetoferritin. Nanoscale 8, 7474-7483. doi: 10.1039/C5NR07144E

Cosenza, S., Ruiz, M., Toupet, K., Jorgensen, C., and Noel, D. (2017). Mesenchymal stem cells derived exosomes and microparticles protect cartilage and bone from degradation in osteoarthritis. Sci. Rep. 7:16214. doi: 10.1038/s41598-017-15376-8

Cosenza, S., Toupet, K., Maumus, M., Luz-Crawford, P., Blanc-Brude, O., Jorgensen, C., et al. (2018). Mesenchymal stem cells-derived exosomes are more immunosuppressive than microparticles in inflammatory arthritis. Theranostics 8, 1399-1410. doi: 10.7150/thno.21072

da Costa Goncalves, F., and Paz, A. H. (2019). Cell membrane and bioactive factors derived from mesenchymal stromal cells: cell-free based therapy for inflammatory bowel diseases. World J. Stem Cells 11, 618-633. doi: 10.4252/wjsc.v11.i9.618

Darnell, M., O'Neil, A., Mao, A., Gu, L., Rubin, L. L., and Mooney, D. J. (2018). Material microenvironmental properties couple to induce distinct transcriptional programs in mammalian stem cells. Proc. Natl. Acad. Sci. U.S.A. 115, E8368-E8377. doi: 10.1073/pnas.1802568115

Donnelly, R. P., Dickensheets, H., and Finbloom, D. S. (1999). The interleukin10 signal transduction pathway and regulation of gene expression in mononuclear phagocytes. J. Interferon Cytokine Res. 19, 563-573. doi: $10.1089 / 107999099313695$

Du, W., Zhang, K., Zhang, S., Wang, R., Nie, Y., Tao, H., et al. (2017). Enhanced proangiogenic potential of mesenchymal stem cell-derived exosomes stimulated by a nitric oxide releasing polymer. Biomaterials 133, 70-81. doi: 10.1016/j.biomaterials.2017.04.030

EL Andaloussi, S., Mager, I., Breakefield, X. O., and Wood, M. J. (2013). Extracellular vesicles: biology and emerging therapeutic opportunities. Nat. Rev. Drug Discov. 12, 347-357. doi: 10.1038/nrd3978

English, K. (2013). Mechanisms of mesenchymal stromal cell immunomodulation. Immunol. Cell Biol. 91, 19-26. doi: 10.1038/icb.2012.56

Ferguson, S. W., Wang, J., Lee, C. J., Liu, M., Neelamegham, S., Canty, J. M., et al. (2018). The microRNA regulatory landscape of MSC-derived exosomes: a systems view. Sci. Rep. 8:1419. doi: 10.1038/s41598-018-19581-x

Fuhrmann, G., Serio, A., Mazo, M., Nair, R., and Stevens, M. M. (2015). Active loading into extracellular vesicles significantly improves the cellular uptake and photodynamic effect of porphyrins. J. Control. Release 205, 35-44. doi: 10.1016/j.jconrel.2014.11.029

Galli, S. J., Borregaard, N., and Wynn, T. A. (2011). Phenotypic and functional plasticity of cells of innate immunity: macrophages, mast cells and neutrophils. Nat. Immunol. 12, 1035-1044. doi: 10.1038/ni.2109

Godoy, J. A. P., Paiva, R. M. A., Souza, A. M., Kondo, A. T., Kutner, J. M., and Okamoto, O. K. (2019). Clinical translation of mesenchymal stromal cell therapy for graft versus host disease. Front Cell Dev Biol. 7:255. doi: $10.3389 /$ fcell.2019.00255

Hao, D., Xiao, W., Liu, R., Kumar, P., Li, Y., Zhou, P., et al. (2017). Discovery and characterization of a potent and specific peptide ligand targeting endothelial progenitor cells and endothelial cells for tissue regeneration. ACS Chem. Biol. 12, 1075-1086. doi: 10.1021/acschembio. $7 \mathrm{~b} 00118$

Harvey, T., Flamenco, S., and Fan, C. M. (2019). A Tppp3(+)Pdgfra(+) tendon stem cell population contributes to regeneration and reveals a shared role for PDGF signalling in regeneration and fibrosis. Nat. Cell Biol. 21, 1490-1503. doi: 10.1038/s41556-019-0417-z

Huang, F., Zhu, X., Hu, X. Q., Fang, Z. F., Tang, L., Lu, X. L., et al. (2013). Mesenchymal stem cells modified with miR-126 release angiogenic factors and activate Notch ligand Delta-like-4, enhancing ischemic angiogenesis and cell survival. Int. J. Mol. Med. 31, 484-492. doi: 10.3892/ijmm.201 2.1200

Huleihel, L., Hussey, G. S., Naranjo, J. D., Zhang, L., Dziki, J. L., Turner, N. J., et al. (2016). Matrix-bound nanovesicles within ECM bioscaffolds. Sci Adv. 2:e1600502. doi: 10.1126/sciadv.1600502 
Hyvarinen, K., Holopainen, M., Skirdenko, V., Ruhanen, H., Lehenkari, P., Korhonen, M., et al. (2018). Mesenchymal stromal cells and their extracellular vesicles enhance the anti-inflammatory phenotype of regulatory macrophages by downregulating the production of interleukin (IL)-23 and IL-22. Front. Immunol. 9:771. doi: 10.3389/fimmu.2018.00771

Kim, H. S., Choi, D. Y., Yun, S. J., Choi, S. M., Kang, J. W., Jung, J. W., et al. (2012). Proteomic analysis of microvesicles derived from human mesenchymal stem cells. J. Proteome Res. 11, 839-849. doi: 10.1021/pr200682z

Kim, J., and Hematti, P. (2009). Mesenchymal stem cell-educated macrophages: a novel type of alternatively activated macrophages. Exp. Hematol. 37, 1445-1453. doi: 10.1016/j.exphem.2009.09.004

Kingery, M. T., Manjunath, A. K., Anil, U., and Strauss, E. J. (2019). Bone marrow mesenchymal stem cell therapy and related bone marrow-derived orthobiologic therapeutics. Curr. Rev. Musculoskelet. Med. 12, 451-459. doi: 10.1007/s12178-019-09583-1

Kosaka, N., Iguchi, H., Yoshioka, Y., Takeshita, F., Matsuki, Y., and Ochiya, T. (2010). Secretory mechanisms and intercellular transfer of microRNAs in living cells. J. Biol. Chem. 285, 17442-17452. doi: 10.1074/jbc.M110.107821

Krzyszczyk, P., Schloss, R., Palmer, A., and Berthiaume, F. (2018). The role of macrophages in acute and chronic wound healing and interventions to promote pro-wound healing phenotypes. Front. Physiol. 9:419. doi: 10.3389/fphys.2018.00419

Lai, R. C., Tan, S. S., Teh, B. J., Sze, S. K., Arslan, F., de Kleijn, D. P., et al. (2012). Proteolytic potential of the MSC exosome proteome: implications for an exosome-mediated delivery of therapeutic proteasome. Int. J. Proteomics 2012:971907. doi: 10.1155/2012/971907

Le Blanc, K., and Mougiakakos, D. (2012). Multipotent mesenchymal stromal cells and the innate immune system. Nat. Rev. Immunol. 12, 383-396. doi: $10.1038 /$ nri3209

Lee, C., Mitsialis, S. A., Aslam, M., Vitali, S. H., Vergadi, E., Konstantinou, G., et al. (2012). Exosomes mediate the cytoprotective action of mesenchymal stromal cells on hypoxia-induced pulmonary hypertension. Circulation 126, 2601-2611. doi: 10.1161/CIRCULATIONAHA.112.114173

Lee, J., Lee, H., Goh, U., Kim, J., Jeong, M., Lee, J., et al. (2016). Cellular engineering with membrane fusogenic liposomes to produce functionalized extracellular vesicles. ACS Appl. Mater. Interfaces 8, 6790-6795. doi: 10.1021/acsami.6b01315

Li, T., Yan, Y., Wang, B., Qian, H., Zhang, X., Shen, L., et al. (2013). Exosomes derived from human umbilical cord mesenchymal stem cells alleviate liver fibrosis. Stem Cells Dev. 22, 845-854. doi: 10.1089/scd.2012.0395

Li, Y., Kong, N., Li, Z., Tian, R., Liu, X., Liu, G., et al. (2019). Bone marrow macrophage M2 polarization and adipose-derived stem cells osteogenic differentiation synergistically promote rehabilitation of bone damage. J. Cell. Biochem. 120, 19891-19901. doi: 10.1002/jcb.29297

Li, Z., Liu, F., He, X., Yang, X., Shan, F., and Feng, J. (2019). Exosomes derived from mesenchymal stem cells attenuate inflammation and demyelination of the central nervous system in EAE rats by regulating the polarization of microglia. Int. Immunopharmacol. 67, 268-280. doi: 10.1016/j.intimp.2018. 12.001

Lo Sicco, C., Reverberi, D., Balbi, C., Ulivi, V., Principi, E., Pascucci, L., et al. (2017). Mesenchymal stem cell-derived extracellular vesicles as mediators of anti-inflammatory effects: endorsement of macrophage polarization. Stem Cells Transl. Med. 6, 1018-1028. doi: 10.1002/sctm.16-0363

Lou, G., Yang, Y., Liu, F., Ye, B., Chen, Z., Zheng, M., et al. (2017). MiR122 modification enhances the therapeutic efficacy of adipose tissue-derived mesenchymal stem cells against liver fibrosis. J. Cell. Mol. Med. 21, 2963-2973. doi: $10.1111 /$ jcmm. 13208

Lu, M., and Huang, Y. (2020). Bioinspired exosome-like therapeutics and delivery nanoplatforms. Biomaterials 242:119925. doi: 10.1016/j.biomaterials.2020.119925

Luan, X., Sansanaphongpricha, K., Myers, I., Chen, H., Yuan, H., and Sun, D. (2017). Engineering exosomes as refined biological nanoplatforms for drug delivery. Acta Pharmacol. Sin. 38, 754-763. doi: 10.1038/aps.2017.12

Lukomska, B., Stanaszek, L., Zuba-Surma, E., Legosz, P., Sarzynska, S., and Drela, K. (2019). Challenges and controversies in human mesenchymal stem cell therapy. Stem Cells Int. 2019:9628536. doi: 10.1155/2019/ 9628536
Ma, J., Zhao, Y., Sun, L., Sun, X., Zhao, X., Sun, X., et al. (2017). Exosomes derived from Akt-modified human umbilical cord mesenchymal stem cells improve cardiac regeneration and promote angiogenesis via activating platelet-derived growth factor D. Stem Cells Transl. Med. 6, 51-59. doi: 10.5966/sctm.2016-0038

Ma, S., Xie, N., Li, W., Yuan, B., Shi, Y., and Wang, Y. (2014). Immunobiology of mesenchymal stem cells. Cell Death Differ. 21, 216-225. doi: $10.1038 /$ cdd.2013.158

Maggini, J., Mirkin, G., Bognanni, I., Holmberg, J., Piazzon, I. M., Nepomnaschy, I., et al. (2010). Mouse bone marrow-derived mesenchymal stromal cells turn activated macrophages into a regulatory-like profile. PLoS ONE 5:e9252. doi: 10.1371/journal.pone.0009252

Mantovani, A., Biswas, S. K., Galdiero, M. R., Sica, A., and Locati, M. (2013). Macrophage plasticity and polarization in tissue repair and remodelling. $J$. Pathol. 229, 176-185. doi: 10.1002/path.4133

Maxson, S., Lopez, E. A., Yoo, D., Danilkovitch-Miagkova, A., and Leroux, M. A. (2012). Concise review: role of mesenchymal stem cells in wound repair. Stem Cells Transl. Med. 1, 142-149. doi: 10.5966/sctm.2011-0018

McElvany, M. D., McGoldrick, E., Gee, A. O., Neradilek, M. B., and Matsen, F. A. 3rd (2015). Rotator cuff repair: published evidence on factors associated with repair integrity and clinical outcome. Am. J. Sports Med. 43, 491-500. doi: $10.1177 / 0363546514529644$

Melief, S. M., Geutskens, S. B., Fibbe, W. E., and Roelofs, H. (2013a). Multipotent stromal cells skew monocytes towards an anti-inflammatory interleukin10-producing phenotype by production of interleukin-6. Haematologica 98, 888-895. doi: 10.3324/haematol.2012.078055

Melief, S. M., Schrama, E., Brugman, M. H., Tiemessen, M. M., Hoogduijn, M. J., Fibbe, W. E., et al. (2013b). Multipotent stromal cells induce human regulatory $\mathrm{T}$ cells through a novel pathway involving skewing of monocytes toward antiinflammatory macrophages. Stem Cells 31, 1980-1991. doi: 10.1002/stem.1432

Mianehsaz, E., Mirzaei, H. R., Mahjoubin-Tehran, M., Rezaee, A., Sahebnasagh, R., Pourhanifeh, M. H., et al. (2019). Mesenchymal stem cell-derived exosomes: a new therapeutic approach to osteoarthritis? Stem Cell Res. Ther. 10:340. doi: 10.1186/s13287-019-1445-0

Moher, D., Liberati, A., Tetzlaff, J., Altman, D. G., and Group, P. (2009). Preferred reporting items for systematic reviews and meta-analyses: the PRISMA statement. PLoS Med 6:e1000097. doi: 10.1371/journal.pmed. 1000097

Moore, J. P., Vinh, A., Tuck, K. L., Sakkal, S., Krishnan, S. M., Chan, C. T., et al. (2015). M2 macrophage accumulation in the aortic wall during angiotensin II infusion in mice is associated with fibrosis, elastin loss, and elevated blood pressure. Am. J. Physiol. Heart Circ. Physiol. 309, H906-917. doi: 10.1152/ajpheart.00821.2014

Mosser, D. M., and Edwards, J. P. (2008). Exploring the full spectrum of macrophage activation. Nat. Rev. Immunol. 8, 958-969. doi: 10.1038/nri2448

Murray, P. J., Allen, J. E., Biswas, S. K., Fisher, E. A., Gilroy, D. W., Goerdt, S., et al. (2014). Macrophage activation and polarization: nomenclature and experimental guidelines. Immunity 41, 14-20. doi: 10.1016/j.immuni.2014.06.008

Nakase, I., and Futaki, S. (2015). Combined treatment with a pH-sensitive fusogenic peptide and cationic lipids achieves enhanced cytosolic delivery of exosomes. Sci. Rep. 5:10112. doi: 10.1038/srep10112

Nemeth, K., Leelahavanichkul, A., Yuen, P. S., Mayer, B., Parmelee, A., Doi, K., et al. (2009). Bone marrow stromal cells attenuate sepsis via prostaglandin $\mathrm{E}(2)$ dependent reprogramming of host macrophages to increase their interleukin10 production. Nat. Med. 15, 42-49. doi: 10.1038/nm.1905

O'Brien, E. M., Risser, G. E., and Spiller, K. L. (2019). Sequential drug delivery to modulate macrophage behavior and enhance implant integration. Adv. Drug Deliv. Rev. 149-150, 85-94. doi: 10.1016/j.addr.2019. 05.005

Oh, J. Y., Roddy, G. W., Choi, H., Lee, R. H., Ylostalo, J. H., Rosa, R. H. Jr., et al. (2010). Anti-inflammatory protein TSG-6 reduces inflammatory damage to the cornea following chemical and mechanical injury. Proc. Natl. Acad. Sci. U.S.A. 107, 16875-16880. doi: 10.1073/pnas.1012 451107

Otsuru, S., Gordon, P. L., Shimono, K., Jethva, R., Marino, R., Phillips, C. L., et al. (2012). Transplanted bone marrow mononuclear cells and MSCs impart clinical benefit to children with osteogenesis imperfecta through 
different mechanisms. Blood 120, 1933-1941. doi: 10.1182/blood-2011-12-4 00085

Pacienza, N., Lee, R. H., Bae, E. H., Kim, D. K., Liu, Q., Prockop, D. J., et al. (2019). In vitro macrophage assay predicts the in vivo antiinflammatory potential of exosomes from human mesenchymal stromal cells. Mol. Ther. Methods Clin. Dev. 13, 67-76. doi: 10.1016/j.omtm.2018. 12.003

Pajarinen, J., Lin, T., Gibon, E., Kohno, Y., Maruyama, M., Nathan, K., et al. (2019). Mesenchymal stem cell-macrophage crosstalk and bone healing. Biomaterials 196, 80-89. doi: 10.1016/j.biomaterials.2017. 12.025

Parekkadan, B., and Milwid, J. M. (2010). Mesenchymal stem cells as therapeutics. Annu. Rev. Biomed. Eng. 12, 87-117. doi: 10.1146/annurev-bioeng-070909-105309

Phan, J., Kumar, P., Hao, D., Gao, K., Farmer, D., and Wang, A. (2018). Engineering mesenchymal stem cells to improve their exosome efficacy and yield for cell-free therapy. J. Extracell. Vesicles 7:1522236. doi: 10.1080/20013078.2018. 1522236

Pittenger, M. (2009). Sleuthing the source of regeneration by MSCs. Cell Stem Cell 5, 8-10. doi: 10.1016/j.stem.2009.06.013

Qu, Y., Zhang, Q., Cai, X., Li, F., Ma, Z., Xu, M., et al. (2017). Exosomes derived from miR-181-5p-modified adipose-derived mesenchymal stem cells prevent liver fibrosis via autophagy activation. J. Cell. Mol. Med. 21, 2491-2502. doi: $10.1111 / \mathrm{jcmm} .13170$

Raposo, G., and Stoorvogel, W. (2013). Extracellular vesicles: exosomes, microvesicles, and friends. J. Cell Biol. 200, 373-383. doi: $10.1083 / \mathrm{jcb} .201211138$

Regenberg, A. C., Hutchinson, L. A., Schanker, B., and Mathews, D. J. (2009). Medicine on the fringe: stem cell-based interventions in advance of evidence. Stem Cells 27, 2312-2319. doi: 10.1002/stem.132

Ridder, K., Keller, S., Dams, M., Rupp, A. K., Schlaudraff, J., Del Turco, D., et al. (2014). Extracellular vesicle-mediated transfer of genetic information between the hematopoietic system and the brain in response to inflammation. PLoS Biol. 12:e1001874. doi: 10.1371/journal.pbio.1001874

Rodero, M. P., and Khosrotehrani, K. (2010). Skin wound healing modulation by macrophages. Int. J. Clin. Exp. Pathol. 3, 643-653.

Saldana, L., Bensiamar, F., Valles, G., Mancebo, F. J., Garcia-Rey, E., and Vilaboa, N. (2019). Immunoregulatory potential of mesenchymal stem cells following activation by macrophage-derived soluble factors. Stem Cell Res. Ther. 10:58. doi: 10.1186/s13287-019-1156-6

Shen, H., Yoneda, S., Abu-Amer, Y., Guilak, F., and Gelberman, R. H. (2020). Stem cell-derived extracellular vesicles attenuate the early inflammatory response after tendon injury and repair. J. Orthop. Res. 38, 117-127. doi: 10.1002/jor.24406

Shi, Y., Su, J., Roberts, A. I., Shou, P., Rabson, A. B., and Ren, G. (2012). How mesenchymal stem cells interact with tissue immune responses. Trends Immunol. 33, 136-143. doi: 10.1016/j.it.2011.11.004

Shi, Z., Wang, Q., and Jiang, D. (2019). Extracellular vesicles from bone marrow-derived multipotent mesenchymal stromal cells regulate inflammation and enhance tendon healing. J. Transl. Med. 17:211. doi: 10.1186/s12967-019-1960-x

Sica, A., and Mantovani, A. (2012). Macrophage plasticity and polarization: in vivo veritas. J. Clin. Invest. 122, 787-795. doi: 10.1172/JCI59643

Silva, A. K., Kolosnjaj-Tabi, J., Bonneau, S., Marangon, I., Boggetto, N., Aubertin, K., et al. (2013). Magnetic and photoresponsive theranosomes: translating cellreleased vesicles into smart nanovectors for cancer therapy. ACS Nano 7, 4954-4966. doi: 10.1021/nn400269x

Skog, J., Wurdinger, T., van Rijn, S., Meijer, D. H., Gainche, L., Sena-Esteves, M., et al. (2008). Glioblastoma microvesicles transport RNA and proteins that promote tumour growth and provide diagnostic biomarkers. Nat. Cell Biol. 10, 1470-1476. doi: $10.1038 /$ ncb 1800

Smyth, T., Petrova, K., Payton, N. M., Persaud, I., Redzic, J. S., Graner, M. W., et al. (2014). Surface functionalization of exosomes using click chemistry. Bioconjug. Chem. 25, 1777-1784. doi: 10.1021/bc500291r

Spiller, K. L., and Koh, T. J. (2017). Macrophage-based therapeutic strategies in regenerative medicine. Adv. Drug Deliv. Rev. 122, 74-83. doi: 10.1016/j.addr.2017.05.010
Stahl, M., Schupp, J., Jager, B., Schmid, M., Zissel, G., Muller-Quernheim, J., et al. (2013). Lung collagens perpetuate pulmonary fibrosis via CD204 and M2 macrophage activation. PLOS ONE 8:e81382. doi: 10.1371/journal.pone.0081382

Stein, M., Keshav, S., Harris, N., and Gordon, S. (1992). Interleukin 4 potently enhances murine macrophage mannose receptor activity: a marker of alternative immunologic macrophage activation. J. Exp. Med. 176, 287-292. doi: $10.1084 /$ jem.176.1.287

Tao, S. C., Guo, S. C., Li, M., Ke, Q. F., Guo, Y. P., and Zhang, C. Q. (2017). Chitosan wound dressings incorporating exosomes derived from MicroRNA-126-overexpressing synovium mesenchymal stem cells provide sustained release of exosomes and heal full-thickness skin defects in a diabetic rat model. Stem Cells Transl. Med. 6, 736-747. doi: 10.5966/sctm.201 6-0275

Tian, Y., Li, S., Song, J., Ji, T., Zhu, M., Anderson, G. J., et al. (2014). A doxorubicin delivery platform using engineered natural membrane vesicle exosomes for targeted tumor therapy. Biomaterials 35, 2383-2390. doi: 10.1016/j.biomaterials.2013.11.083

Tidball, J. G. (2011). Mechanisms of muscle injury, repair, and regeneration. Compr. Physiol. 1, 2029-2062. doi: 10.1002/cphy.c100092

Vakhshiteh, F., Atyabi, F., and Ostad, S. N. (2019). Mesenchymal stem cell exosomes: a two-edged sword in cancer therapy. Int. J. Nanomedicine 14, 2847-2859. doi: $10.2147 /$ IJN.S200036

Valadi, H., Ekstrom, K., Bossios, A., Sjostrand, M., Lee, J. J., and Lotvall, J. O. (2007). Exosome-mediated transfer of mRNAs and microRNAs is a novel mechanism of genetic exchange between cells. Nat. Cell Biol. 9, 654-659. doi: $10.1038 /$ ncb1596

Varol, C., Mildner, A., and Jung, S. (2015). Macrophages: development and tissue specialization. Annu. Rev. Immunol. 33, 643-675. doi: 10.1146/annurev-immunol-032414-112220

Wang, B., Yao, K., Huuskes, B. M., Shen, H. H., Zhuang, J., Godson, C., et al. (2016). Mesenchymal stem cells deliver exogenous MicroRNA-let7c via exosomes to attenuate renal fibrosis. Mol. Ther. 24, 1290-1301. doi: 10.1038/mt. 2016.90

Wang, Y., He, G., Guo, Y., Tang, H., Shi, Y., Bian, X., et al. (2019). Exosomes from tendon stem cells promote injury tendon healing through balancing synthesis and degradation of the tendon extracellular matrix. J. Cell. Mol. Med. 23, 5475-5485. doi: $10.1111 / j \mathrm{cmm} .14430$

Waterman, R. S., Tomchuck, S. L., Henkle, S. L., and Betancourt, A. M. (2010). A new mesenchymal stem cell (MSC) paradigm: polarization into a pro-inflammatory $\mathrm{MSC} 1$ or an Immunosuppressive MSC2 phenotype. PLoS ONE 5:e10088. doi: 10.1371/journal.pone.00 10088

Wells, K., and Julia, H. L. (2009). Study quality assessment in systematic reviews of research on intervention effects. Res. Soc. Work Pract. 19, 52-62. doi: $10.1177 / 1049731508317278$

Willis, G. R., Kourembanas, S., and Mitsialis, S. A. (2017). Toward exosome-based therapeutics: isolation, heterogeneity, and fit-forpurpose potency. Front. Cardiovasc. Med. 4:63. doi: 10.3389/fcvm.2017. 00063

Wolfe, A. R., Trenton, N. J., Debeb, B. G., Larson, R., Ruffell, B., Chu, K., et al. (2016). Mesenchymal stem cells and macrophages interact through IL-6 to promote inflammatory breast cancer in pre-clinical models. Oncotarget 7 , 82482-82492. doi: 10.18632/oncotarget.12694

Wolfers, J., Lozier, A., Raposo, G., Regnault, A., Thery, C., Masurier, C., et al. (2001). Tumor-derived exosomes are a source of shared tumor rejection antigens for CTL cross-priming. Nat. Med. 7, 297-303. doi: 10.1038/85438

Yang, D. H., and Yang, M. Y. (2019). The Role of Macrophage in the pathogenesis of osteoporosis. Int. J. Mol. Sci. 20:2093. doi: 10.3390/ijms20092093

Yoo, S. W., Chang, D. Y., Lee, H. S., Kim, G. H., Park, J. S., Ryu, B. Y., et al. (2013). Immune following suppression mesenchymal stem cell transplantation in the ischemic brain is mediated by TGF-beta. Neurobiol. Dis. 58, 249-257. doi: 10.1016/j.nbd.2013.06.001

Zhang, S., Chuah, S. J., Lai, R. C., Hui, J. H. P., Lim, S. K., and Toh, W. S. (2018). MSC exosomes mediate cartilage repair by enhancing proliferation, attenuating apoptosis and modulating immune reactivity. Biomaterials 156, 16-27. doi: 10.1016/j.biomaterials.2017.11.028 
Zhang, Z., Dombroski, J. A., and King, M. R. (2020). Engineering of exosomes to target cancer metastasis. Cell. Mol. Bioeng. 13, 1-16. doi: 10.1007/s12195-019-00607-X

Zhao, Y., Sun, X., Cao, W., Ma, J., Sun, L., Qian, H., et al. (2015). Exosomes derived from human umbilical cord mesenchymal stem cells relieve acute myocardial ischemic injury. Stem Cells Int. 2015:761643. doi: 10.1155/2015/7 61643

Zomer, A., Maynard, C., Verweij, F. J., Kamermans, A., Schafer, R., Beerling, E., et al. (2015). In vivo imaging reveals extracellular vesiclemediated phenocopying of metastatic behavior. Cell 161, 1046-1057. doi: 10.1016/j.cell.2015.04.042
Conflict of Interest: The authors declare that the research was conducted in the absence of any commercial or financial relationships that could be construed as a potential conflict of interest.

Copyright (c) 2020 Xu, Lee, Wang, Huang, Shin, Wang, Wan, Zhu, Yung and Lee. This is an open-access article distributed under the terms of the Creative Commons Attribution License (CC BY). The use, distribution or reproduction in other forums is permitted, provided the original author(s) and the copyright owner(s) are credited and that the original publication in this journal is cited, in accordance with accepted academic practice. No use, distribution or reproduction is permitted which does not comply with these terms. 